\title{
Right internal thoracic artery versus radial artery as the second best arterial conduit: Insights from a meta-analysis of propensity-matched data on long-term survival
}

\author{
Umberto Benedetto, MD, PhD, ${ }^{\mathrm{a}}$ Mario Gaudino, MD, ${ }^{\mathrm{b}}$ Massimo Caputo, MD, ${ }^{\mathrm{a}}$ Robert F. Tranbaugh, MD, \\ Christopher Lau, MD, ${ }^{\mathrm{b}}$ Antonino Di Franco, MD, ${ }^{\mathrm{b}}$ Colin Ng, MBBS, ${ }^{\mathrm{c}}$ Leonard N. Girardi, MD, ${ }^{\mathrm{b}}$ and \\ Gianni D. Angelini, MD ${ }^{\mathrm{a}}$
}

\begin{abstract}
Objective(s): We conducted a meta-analysis of propensity score-matching (PSM) studies comparing long-term survival of patients receiving right internal thoracic artery (RITA) versus radial artery (RA) as a second arterial conduit for coronary artery bypass grafting.

Methods: A literature search was conducted using MEDLINE, EMBASE, and Web of Science to identify relevant articles. Primary endpoint was long-term mortality. Secondary endpoints were operative mortality, incidence of sternal wound infection, and repeat revascularization. Binary events were pooled using the DerSimonian and Laird method. For time-to-event outcomes, estimates of log hazard ratio (HR) and standard errors obtained were combined using the generic inversevariance method.
\end{abstract}

Results: A total of 8 PSM studies were finally selected including 15,374 patients (RITA, 6739; RA, 8635) with 2992 matched pairs for final comparison. Mean follow-up time ranged from 45 to 168 months. When compared with RA, RITA was associated with a lower risk reduction of late death $(\mathrm{HR}, 0.75 ; 95 \%$ confidence interval $[\mathrm{CI}], 0.58-0.97 ; P=.028$ ) and repeat revascularization (HR, $0.37 ; 95 \% \mathrm{CI}, 0.16-0.85 ; P=.03)$. On the other hand, RITA did not increase operative mortality (odds ratio [OR], $1.53 ; 95 \% \mathrm{CI}, 0.97-2.39 ; P=.07$ ). RITA was associated with an increased risk of sternal wound complication when pedicled harvesting was used $(\mathrm{OR}, 3.18 ; 95 \% \mathrm{CI}, 1.34-7.57)$, but not with skeletonized harvesting (OR, 1.07; 95\% CI, 0.67-1.71).

Conclusions: The present PSM data meta-analysis suggests that the use of RITA compared with RA was associated with superior long-term survival and freedom from repeat revascularization, with similar operative mortality and incidence of sternal wound complication when the skeletonized harvesting technique was used. (J Thorac Cardiovasc Surg 2016;152:1083-91)

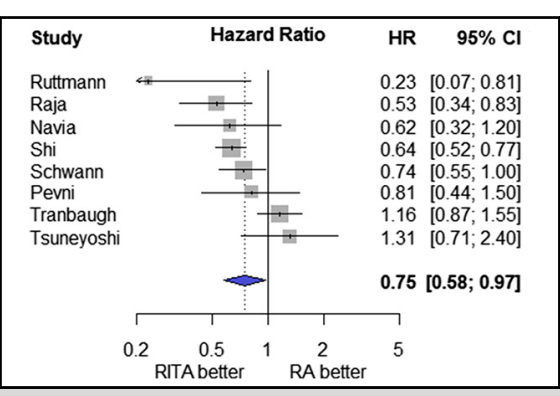

By pooling data from 8 propensity score-matching studies, the right internal thoracic artery (RITA) was found to be associated with a $25 \%$ risk reduction of late death compared with the radial artery (RA).

\section{Central Message}

Compared with the radial artery, the right internal thoracic artery is associated with superior long-term survival and freedom from reintervention when used as second arterial conduit.

\section{Perspective}

The choice of the right internal thoracic artery or radial artery as a second conduit in coronary artery bypass graft surgery remains controversial The present propensity-matched data metaanalysis showed that the right internal thoracic artery was associated with superior long-term survival and freedom from repeat revascularization, with similar operative mortality and incidence of sternal wound complication when the skeletonized harvesting technique was used.

See Editorial Commentary page 1092.

\footnotetext{
From the ${ }^{\mathrm{a} B r i s t o l}$ Heart Institute, University of Bristol, School of Clinical Sciences, Bristol, United Kingdom; ${ }^{b}$ Department of Cardiothoracic Surgery, Weill Cornell Medical College, New York, NY; and ${ }^{\mathrm{c}}$ National University of Singapore, Singapore.

This study was supported by the British Heart Foundation (grant CH/92027/7163) and the NIHR Bristol Cardiovascular Biomedical Research Unit.

U.B. and M.G. contributed equally to the paper.

Received for publication Jan 28, 2016; revisions received April 13, 2016; accepted for publication May 19, 2016; available ahead of print June 22, 2016.

Address for reprints: Umberto Benedetto, $\mathrm{MD}, \mathrm{PhD}$, Bristol Heart Institute, University of Bristol, Upper Maudlin St, Bristol BS2 8HW, United Kingdom (E-mail: umberto.benedetto@bristol.ac.uk).

$0022-5223 / \$ 36.00$

Copyright (c) 2016 by The American Association for Thoracic Surgery

http://dx.doi.org/10.1016/j.jtcvs.2016.05.022
}

Despite increasing recognition that multiple arterial conduits improve long-term outcomes following coronary artery bypass grafting $(\mathrm{CABG}),{ }^{1}$ the quest for the second best arterial conduit to supplement the left internal thoracic artery continues. ${ }^{2}$ In particular, whether the use of the right internal

Scanning this QR code will take you to supplemental figures and tables for this article.

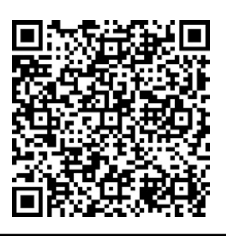




$$
\begin{aligned}
& \text { Abbreviations and Acronyms } \\
& \begin{aligned}
\text { CABG } & =\text { coronary artery bypass grafting } \\
\text { CI } & =\text { confidence interval } \\
\text { HR } & =\text { hazard ratio } \\
\text { OR } & =\text { odds ratio } \\
\text { PSM } & =\text { propensity score matching } \\
\text { RA } & =\text { radial artery } \\
\text { RAPCO } & =\text { Radial Artery Patency and Clinical } \\
& \text { Outcomes } \\
\text { RCT } & =\text { randomized controlled trial } \\
\text { RITA } & \text { right internal thoracic artery }
\end{aligned}
\end{aligned}
$$

thoracic artery (RITA) confers a survival advantage when compared with the radial artery (RA) still needs to be determined. ${ }^{3}$ The lack of clear evidence, the potentially increased sternal wound complication rate, and the perceived technical complexity using bilateral internal thoracic arteries often result in the RA as the preferred second conduit of choice. ${ }^{1}$ To date, only a single randomized controlled trial (RCT), the Radial Artery Patency and Clinical Outcomes (RAPCO) study, ${ }^{3}$ has been published in the literature, largely underpowered to detect any difference in long-term survival between the RITA and RA groups. Propensity scorematching (PSM)-based analysis of observational data is emerging as an attractive alternative in view of the paucity of evidence from RCTs, and can be relied on as evidence when RCTs are not possible. ${ }^{4}$ Several large PSM studies comparing RITA with RA have been recently published with inconclusive findings. ${ }^{5-12}$ Here, we propose to overcome the potential limitations related to underpowered individual reports by conducting a meta-analysis of PSM studies comparing RITA with RA as a second arterial conduit on long-term survival in patients undergoing CABG.

\section{METHODS}

\section{Search Strategy and Selection of Studies}

This systematic review was conducted according to the Preferred Reporting Items for Systematic Reviews and Meta-Analyses (PRISMA) guidelines $^{13}$ (see Table E1 for the PRISMA checklist). A literature search was conducted using MEDLINE, EMBASE, and Web of Science to identify relevant articles on January 2016. Observational studies included in the present meta-analysis met the following criteria: (1) patients underwent first time isolated CABG; (2) comparison of long-term survival of patients receiving RITA versus RA as second arterial conduit was made; and (3) PSM was used to account for non-random allocation to treatment (RITA vs RA). Non-English language, review articles, and editorials were excluded. Search terms used the controlled vocabularies of MEDLINE and EMBASE alone or in combination with text words including "radial artery," "right internal thoracic artery," "bilateral internal thoracic artery," "propensity score," and "propensity score matching." Two reviewers (U.B. and M.G.) independently reviewed the results on titles and abstracts to determine whether the study met the inclusion criteria. In the case of disagreement, an agreement was negotiated. In the case of several publications with overlapping study populations, the largest sample size study with longest follow-up available was selected. The quality of included studies was assessed with the Newcastle-Ottawa Scale for observational studies. ${ }^{14}$ The total score was 9 stars, and the quality was graded as low level $(<6$ stars) or high level ( $\geq 6$ stars).

\section{Data Extraction}

Microsoft Office Excel 2010 (Microsoft, Redmond, Wash) was used for data extraction. Data extraction of all included studies was performed independently by 2 researchers (U.B. and A.D.F). In the case of disagreement about extracted data, an agreement was negotiated. Study design, study period, country, and center where the study was conducted, unmatched and matched sample size, designated target for experimental graft, PSM methods, completeness of follow-up, and follow-up duration were documented. The following patient characteristics in the unmatched and matched groups were also registered: age, female gender, diabetes mellitus, reduced left ventricular ejection fraction (as defined by authors), chronic obstructive pulmonary disease, renal impairment (as defined by authors), and predicted operative risk according to the EuroSCORE or Society of Thoracic Surgeons score. ${ }^{15}$

Long-term mortality was the primary endpoint of our meta-analysis. Secondary endpoints were operative mortality, incidence of sternal wound complication, and repeat revascularization. Time-to-event outcomes (longterm mortality and repeat revascularization) were extracted as hazard ratios (HRs) and their variance from the matched sample. When only the graphic survival curves and the number of persons at risk at each of several time points in the PSM comparison groups were provided, the method of Williamson et $\mathrm{al}^{16}$ was used to obtain the HR estimates and variance. Binary endpoints (operative mortality and sternal wound complication) were extracted as event and sample size in the matched groups.

\section{Statistical Analysis}

The meta-analysis was pre-specified to use a random effects model because of the anticipated variety in study designs and populations and thus a more conservative value was obtained. Binary event data from the RITA versus RA cohorts were computed as odds ratios (ORs) and associated $95 \%$ confidence intervals (CIs) and pooled using the method of DerSimonian and Laird. ${ }^{17}$ For time-to-event outcomes, estimates of log HRs and standard errors obtained were combined using the generic inversevariance method. The $I^{2}$ statistic was used to estimate the percentage of total variation across studies due to heterogeneity rather than chance. Suggested thresholds for heterogeneity were used, with $I^{2}$ values of $25 \%-49 \%, 50 \%-74 \%$, and $\geq 75 \%$ indicative of low, moderate, and high heterogeneity, respectively. ${ }^{18}$ Publication bias was evaluated using visual inspection of funnel plot asymmetry and the Begg and Mazumdar rank correlation test. ${ }^{19}$ For the primary outcome, secondary analyses were conducted including leave-one-out sensitivity analyses and a radial (or Galbraith) plot to assess the influence of outliers. The radial plot is designed to assess the extent of heterogeneity between studies. The y axis shows the (logtransformed) effect size divided by its standard error (z score) and the inverse of the standard error on the $\mathrm{x}$ axis. Each study is represented by a single dot, and a regression line runs centrally through the plot. Parallel to the regression line, at a 2-standard deviation distance, 2 lines create an interval in which most dots would be expected to decrease if the studies were estimating a single fixed parameter. A line projected from $(0,0)$ through a particular point within the plot onto this arc indicates the value of the observed outcome for that point. In addition, estimates obtained from PSM were pooled with those from available RCTs. Finally, to support the external validity of the main analysis, estimates obtained from all unmatched populations (including observational non-PSM studies) were pooled. Subgroup analysis was conducted according to the target selected for the experimental conduit (left coronary artery system only vs both left and right coronary artery systems) and to the internal thoracic artery harvesting technique. A subgroup analysis on the incidence of sternal wound complication according to the internal thoracic artery harvesting technique (skeletonized vs pedicled) was also conducted. Statistical analysis was 


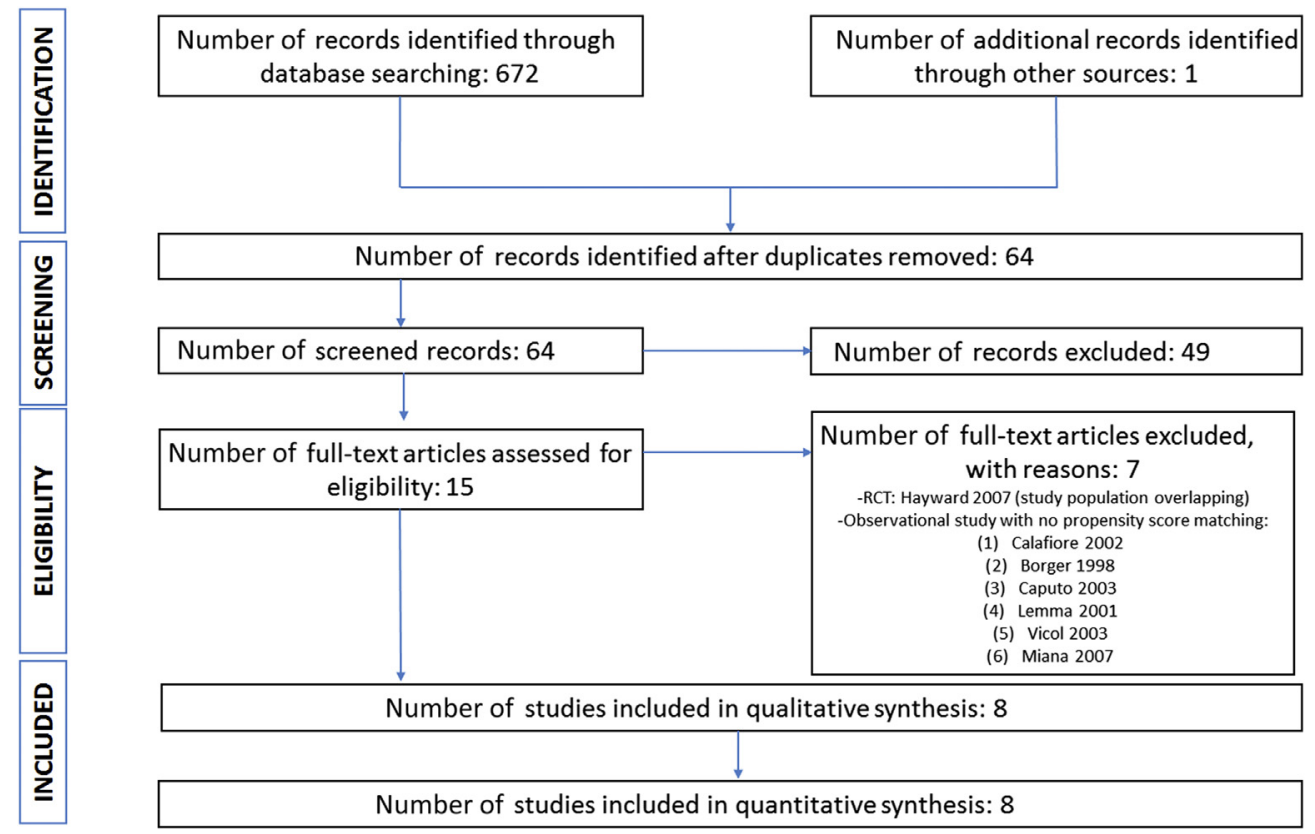

FIGURE 1. Flow chart for study selection. RCT, Randomized controlled trial.

conducted using the meta package for $\mathrm{R}$ (meta: General Package for Meta-Analysis. R package version 4.3-2. https://CRAN.R-project.org/ package $=$ meta).

\section{RESULTS}

\section{Selected Studies}

From 673 abstracts, we selected 15 full-text articles fitting our selection criteria. After evaluating the full-text articles, we excluded 6 observational studies ${ }^{20-25}$ that did not perform PSM adjustment, and 1 RCT, the RAPCO trial $^{3}$ (Table E2). A total of 8 PSM studies ${ }^{5-12}$ were finally selected for the systematic review and meta-analysis. Of note, the study population in the RAPCO trial ${ }^{3}$ was also part of a large Australian multicenter registry ${ }^{10}$ included in the main analysis. An outline of the systematic review process is depicted in Figure 1. An overview of the PSM studies is summarized in Tables 1 and 2 (variables included for PSM are summarized in Table E3). Overall, selected studies reported on 15,374 patients (RITA, 6739; RA, 8635) with 2992 matched pairs for final comparisons. Risk factor distribution before and after matching for each study is reported in Table 3. PSM and unmatched populations presented a similar preoperative risk factors distribution. The Newcastle-Ottawa Scale confirmed a high quality level for all PSM studies included in the main analysis (Table E4).

\section{Primary Analysis on Long-Term Mortality}

All studies reported on comparisons of long-term mortality. The mean follow-up time ranged from 45 to 168 months. The RITA group was associated with a statistically significant $25 \%$ risk reduction of late death when compared with the RA group (HR, $0.75 ; 95 \%$ CI, $0.58-0.97 ; P=.028$; Figure 2). We found a moderate heterogeneity among the studies $\left(I^{2}=66.5 \%\right.$; $95 \%$ CI, $\left.29.1 \%-84.2 \%\right)$. No publication bias was found $(P=.62$; Figure E1).

\section{Operative Mortality}

All studies selected reported on comparisons of operative mortality, although different definitions were adopted (Table E5). Operative mortality rate ranged from $0.7 \%$ to $4.03 \%$ and from $0 \%$ to $3.4 \%$ in the RITA and RA groups, respectively, and pooled estimates showed no significant difference between the 2 groups (OR, $1.53 ; 95 \% \mathrm{CI}$, $0.97-2.39 ; P=.07$; Figure $3, A$ ). There was no significant heterogeneity among the studies $\left(I^{2}=0 \% ; 95 \% \mathrm{CI}, 0 \%\right.$ $56.5 \%)$. No publication bias was found $(P=.80$; Figure E2, A).

\section{Sternal Wound Complications}

All but one ${ }^{5}$ study reported on sternal wound complications in the matched population, although different definitions were adopted. These ranged from $1.7 \%$ to $3.2 \%$ and from $0 \%$ to $3.6 \%$ in the RITA and RA groups, respectively. The pooled estimates showed a trend toward a higher incidence of sternal wound complications in patients receiving RITA (OR, 1.50; 95\% CI, 0.86-2.60; $P=.15$; Figure 3, $B$ ). Low-to-moderate heterogeneity among studies was found $\left(I^{2}=43.4 \% ; 95 \%\right.$ CI, 0\%-76.2\%). Subgroup analysis according to the internal thoracic artery harvesting technique showed that RITA was associated with a significant 3-fold increased risk of sternal wound complication when pedicled 
TABLE 1. Overview of propensity score-matching studies included in the primary analysis

\begin{tabular}{|c|c|c|c|c|c|c|c|}
\hline Study & $\begin{array}{c}\text { Year of } \\
\text { publication }\end{array}$ & Country & Centers & Study period & Target & $\begin{array}{l}\text { Outcomes of } \\
\text { interest reported }\end{array}$ & ITA-H \\
\hline Navia et $\mathrm{al}^{5}$ & 2014 & Argentina & $\begin{array}{l}\text { Cardiovascular } \\
\text { Institute of } \\
\text { Buenos Aires }\end{array}$ & $2003-2011$ & LCA/RCA & $\begin{array}{l}\text { Hospital mortality, deep } \\
\text { sternal wound infection } \\
\text { (not in the matched } \\
\text { population) } \\
\text { Late survival, } \\
\text { readmission/ } \\
\text { reintervention }\end{array}$ & Skeleton \\
\hline Pevni et $\mathrm{al}^{6}$ & 2016 & Israel & $\begin{array}{l}\text { Tel Aviv Medical } \\
\text { Center }\end{array}$ & $1996-2010$ & LCA only & $\begin{array}{l}\text { Operative mortality, deep } \\
\text { sternal infection, late } \\
\text { survival }\end{array}$ & Skeleton \\
\hline Raja et $\mathrm{al}^{7}$ & 2014 & $\begin{array}{l}\text { United } \\
\text { Kingdom }\end{array}$ & Harefield Hospital & $2001-2013$ & LCA/RCA & $\begin{array}{l}\text { Operative mortality, } \\
\text { sternal wound } \\
\text { infection, late mortality, } \\
\text { repeat revascularization }\end{array}$ & Pedicled/Skeleton \\
\hline 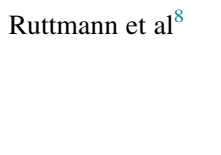 & 2011 & Austria & $\begin{array}{l}\text { Innsbruck Medical } \\
\text { University }\end{array}$ & $2001-2010$ & LCA only & $\begin{array}{l}\text { Operative mortality, } \\
\text { Sternal dehiscence, late } \\
\text { survival, repeat } \\
\text { revascularization }\end{array}$ & Pedicled/Skeleton \\
\hline Schwann et $\mathrm{al}^{9}$ & 2014 & United States & $\begin{array}{l}\text { University of Toledo, } \\
\text { Mercy Saint Vincent } \\
\text { (Toledo, Ohio), Yale } \\
\text { New Haven Hospital }\end{array}$ & $1987-2011$ & LCA only & $\begin{array}{l}\text { 30-d mortality, deep } \\
\text { sternal infection, late } \\
\text { survival }\end{array}$ & Pedicled \\
\hline Shi et $\mathrm{al}^{10}$ & 2015 & Australia & $\begin{array}{l}\text { Austin Hospital, Epworth } \\
\text { Hospital Richmond, } \\
\text { Epworth Eastern } \\
\text { Hospital, Knox Hospital, } \\
\text { Royal Melbourne } \\
\text { Hospital, St Vincent's } \\
\text { Hospital } \\
\text { Melbourne, Warringal } \\
\text { Hospital }\end{array}$ & $1995-2010$ & LCA only & $\begin{array}{l}\text { 30-d mortality, deep } \\
\text { sternal wound } \\
\text { infection, late survival }\end{array}$ & Pedicled/Skeleton \\
\hline Tranbaugh et $\mathrm{al}^{11}$ & 2013 & United States & $\begin{array}{l}\text { Beth Israel Medical } \\
\text { Center, St. Luke's } \\
\text { Roosevelt Hospital } \\
\text { Center }\end{array}$ & $1995-2009$ & LCA only & $\begin{array}{l}\text { Surgical mortality, sternal } \\
\text { wound infection, late } \\
\text { survival, symptom- } \\
\text { driven cardiac } \\
\text { catheterization }\end{array}$ & Pedicled \\
\hline Tsuneyoshi et a ${ }^{12}$ & 2015 & Japan & $\begin{array}{l}\text { Kurashiki Central } \\
\text { Hospital }\end{array}$ & $2000-2013$ & LCA only & $\begin{array}{l}\text { Hospital death, deep } \\
\text { sternal wound } \\
\text { infection, late survival }\end{array}$ & Skeleton \\
\hline
\end{tabular}

ITA-H, Internal thoracic artery harvesting; $L C A$, left coronary artery; $R C A$, right coronary artery.

harvesting only was used ${ }^{9,11}(\mathrm{OR}, 3.18$; 95\% CI, 1.347.57), whereas the 2 groups were comparable in studies where a skeletonized approach was used ${ }^{6-8,10,12}$ (OR, 1.07; 95\% CI, 0.67-1.71) (test for subgroup differences $P=.12)$. No publication bias was found $(P=.17$; Figure E2, $B$ ).

\section{Repeat Revascularization}

Three studies only reported on the incidence of repeat revascularization in the matched population..$^{5,7,8}$ The pooled estimate showed that RITA was associated with a significantly lower risk of repeat revascularization (HR,
0.37; 95\% CI, 0.16-0.85; $P=.03$; Figure 3, C). However, heterogeneity was significantly higher between the 3 studies $\left(I^{2}=74.7 \% ; 95 \%\right.$ CI, $\left.15.9 \%-92.4 \%\right)$. No significant publication bias was found $(P=.11$; Figure $\mathrm{E} 2, C)$.

\section{Secondary Analyses on Long-Term Survival}

The forest plots of the leave-one-out sensitivity analysis (Figure 4, left) and the radial plot (Figure 4, right) showed that there were no significant outliers in the meta-analysis. The survival advantage by choosing RITA was also confirmed by pooling PSM studies with the RAPCO trial (HR, 0.77; 95\% CI, 0.60-0.99; $I^{2}=64.7 \% ; P=.04$ ) 
TABLE 2. Overview of propensity score-matching methods in studies included in the primary analysis

\begin{tabular}{|c|c|c|c|c|c|c|c|c|c|c|}
\hline Study & $\begin{array}{c}\text { UNM } \\
\text { RITA, } \mathbf{n}\end{array}$ & $\begin{array}{r}\text { UNM } \\
\text { RA, n } \\
\end{array}$ & $\begin{array}{c}\text { PSM } \\
\text { RITA, n }\end{array}$ & $\begin{array}{l}\text { PSM } \\
\text { RA, n }\end{array}$ & PSM methodology & $\begin{array}{c}\text { Methods for } \\
\text { comparison } \\
\text { accounting for } \\
\text { matched groups }\end{array}$ & Follow-up (mo) & $\begin{array}{c}\text { Completeness } \\
\text { of follow-up (\%) }\end{array}$ & $\begin{array}{c}\text { Proportional } \\
\text { hazard } \\
\text { assumption }\end{array}$ & $\begin{array}{c}\text { PSM-HR } \\
\text { for mortality } \\
\text { provided } \\
\end{array}$ \\
\hline Navia et $\mathrm{al}^{5}$ & 1447 & 253 & 149 & 149 & $\begin{array}{l}\text { 5-digit 1:1 matching } \\
\text { without replacement }\end{array}$ & $\begin{array}{c}\text { Not specified } \\
(\log \text { rank })\end{array}$ & Mean, 45; IQR, 24-66 & 94.1 & Not reported & No \\
\hline Pevni et $\mathrm{al}^{6}$ & 1329 & 389 & 268 & 268 & $\begin{array}{l}\text { 1:1 matching with a } 5 \% \\
\text { difference as a } \\
\text { matching threshold } \\
\text { value }\end{array}$ & $\begin{array}{l}\text { Yes (Cox stratified on } \\
\text { matched pairs) }\end{array}$ & $\begin{array}{l}\text { Mean, } 168 ; 95 \% \text { CI, } \\
\quad 161-179\end{array}$ & 97 & Not reported & Yes \\
\hline Raja et $\mathrm{al}^{7}$ & 747 & 779 & 510 & 510 & $\begin{array}{l}\text { Greedy } 1: 1 \text { matching } \\
\text { with caliper of width } \\
\text { of } 0.20 \text { SD of the logit } \\
\text { of the PSM }\end{array}$ & $\begin{array}{l}\text { Yes (Klein and } \\
\text { Moeschberger) }\end{array}$ & Mean, 96; IQR, 36-124 & 100 & Not reported & Yes \\
\hline Ruttmann et $\mathrm{al}^{8}$ & 277 & 724 & 277 & 277 & $\begin{array}{l}\text { 2-digit 1:1 matching } \\
\text { without replacement }\end{array}$ & $\begin{array}{l}\text { Yes (Cox stratified on } \\
\text { matched pairs) }\end{array}$ & $\begin{array}{l}\text { Mean, 58; } \\
\quad \text { range, 3-112 }\end{array}$ & Not reported & Not reported & Yes \\
\hline Schwann et $\mathrm{al}^{9}$ & 641 & 3095 & 551 & 551 & $\begin{array}{l}\text { Nearest-neighbor } \\
\text { matching caliper of } \\
\text { width } \pm 1 \% \\
\text { difference in PSM }\end{array}$ & $\begin{array}{l}\text { Not specified (Cox } \\
\text { regression) }\end{array}$ & Range, 3-189 & 100 & Not reported & Yes \\
\hline Shi et $\mathrm{al}^{10}$ & 912 & 1909 & 591 & 591 & $\begin{array}{l}\text { Greedy } 1: 1 \text { matching } \\
\text { with a fixed caliper } \\
\text { width of } 0.05\end{array}$ & $\begin{array}{l}\text { Yes (Klein and } \\
\text { Moeschberger) }\end{array}$ & NA & 100 & Not reported & No \\
\hline $\begin{array}{l}\text { Tranbaugh } \\
\text { et }^{11}{ }^{11}\end{array}$ & 1154 & 1334 & 528 & 528 & $\begin{array}{l}\text { Nearest-neighbor, } \\
\text { caliper-constrained } \\
\text { matching technique }\end{array}$ & $\begin{array}{l}\text { Not specified (Cox } \\
\text { regression) }\end{array}$ & $\begin{array}{r}\text { RITA, } 102 \pm 55 \\
\text { RA, } 108 \pm 52\end{array}$ & Not reported & Reported & Yes \\
\hline $\begin{array}{l}\text { Tsuneyoshi } \\
\text { et } \mathrm{al}^{12}\end{array}$ & 232 & 152 & 118 & 118 & $\begin{array}{l}\text { 1:1 matching; method } \\
\text { not reported }\end{array}$ & Not specified (log rank) & RITA, 73; RA, 94 & 91 & Not reported & No \\
\hline
\end{tabular}

(Figure E3). All but 1 PSM study ${ }^{7}$ and all but 2 non-PSM observational cohorts ${ }^{24,25}$ reported on late mortality in the overall population. Pooled estimates from unmatched populations supported a survival benefit of RITA over RA (HR, 0.74; 95\% CI, 0.56-0.98; $P=.03 ; I^{2}=77.5 \%$; Figure E4). Subgroup analysis showed that, compared with RA, the use of RITA was associated with better longterm survival when used to graft either the left coronary artery system only (HR, $0.81 ; 95 \% \mathrm{CI}, 0.60-1.10)$ or both the left and right coronary systems (HR, 0.56 ; $95 \%$ CI, 0.380.81 ; test for subgroup differences $P=.12$; Figure E5), and no significant differences were found between studies where skeletonized harvesting ${ }^{5-8,10,12}$ (HR, 0.67; 95\% CI, $0.50-0.89)$ versus pedicled harvesting only ${ }^{9,1}$ was used (test for subgroup differences $P=.22$ ).

\section{DISCUSSION}

The main finding of the present PSM data meta-analysis is that, compared with RA, the use of RITA was associated with superior long-term survival and lower incidence of repeat revascularization in patients undergoing CABG with an additional arterial conduit. The use of RITA was associated with superior survival regardless of the target coronary location.

Moreover, the use of RITA did not significantly increase operative mortality and, when harvested as a skeletonized conduit, RITA did not increase the risk of sternal wound complication compared with RA. However, when harvested as a pedicle, RITA was found to be associated with 3-fold increased risk of sternal wound complication.

Despite a slow initial adoption, multiple arterial grafting is now widely advocated by the cardiovascular community. The use of both RITA and RA has been shown to be associated with better long-term survival compared with the traditional strategy using a single internal thoracic artery and additional saphenous vein grafts. ${ }^{9}$ Contention still remains on whether RITA is superior to RA in terms of long-term survival and patency rate. ${ }^{10}$ The only randomized direct comparison in the literature is the RAPCO ${ }^{3}$ which randomized 196 patients to RITA and 193 to RA. At mid-term follow-up, no significant differences in terms of angiographic patency and clinical outcome were found. However, the trial was largely underpowered to detect significant differences in survival between the 2 groups. On the other hand, results of larger observational studies have been discordant and inconclusive. ${ }^{9,10}$

Along with large registry data, meta-analysis of PSM data is emerging as an attractive alternative in view of the paucity of evidence from $\mathrm{RCT}^{4}$ and it overcomes potential limitations related to underpowered individual studies. By pooling data from PSM studies, we found that the use of RITA was associated with a $25 \%$ risk reduction of late 
TABLE 3. Risk factor distribution in the unmatched and matched populations in studies included in the primary analysis

\begin{tabular}{|c|c|c|c|c|c|c|c|c|c|c|c|c|c|c|}
\hline & \multicolumn{7}{|c|}{ Unmatched } & \multicolumn{7}{|c|}{ Propensity score matched } \\
\hline & $\begin{array}{c}\text { Age }(y) \\
\text { mean } \pm \text { SD }\end{array}$ & $\begin{array}{c}\text { Female } \\
(\%)\end{array}$ & $\begin{array}{l}\text { DM } \\
(\%)\end{array}$ & $\begin{array}{l}\text { LVD } \\
(\%)\end{array}$ & $\begin{array}{c}\text { COPD } \\
(\%)\end{array}$ & $\begin{array}{l}\text { RD } \\
(\%)\end{array}$ & $\begin{array}{l}\text { Operative } \\
\text { risk }\end{array}$ & $\begin{array}{c}\text { Age }(y) \\
\text { mean } \pm \text { SD }\end{array}$ & $\begin{array}{c}\text { Female } \\
(\%)\end{array}$ & $\begin{array}{l}\text { DM } \\
(\%)\end{array}$ & $\begin{array}{l}\text { LVD } \\
(\%)\end{array}$ & $\begin{array}{c}\text { COPD } \\
(\%)\end{array}$ & $\begin{array}{l}\text { RD } \\
(\%)\end{array}$ & $\begin{array}{l}\text { Operative } \\
\text { risk }\end{array}$ \\
\hline \multicolumn{15}{|c|}{$\overline{\text { Navia et al }}{ }^{5}$} \\
\hline RITA & $63 \pm 9$ & 8 & 26 & 20 & NR & 4 & $2.7 \pm 2.3 *$ & $68 \pm 8$ & 17 & 30 & 30 & NR & 6 & $3.9 \pm 2.4^{*}$ \\
\hline RA & $69 \pm 10$ & 12 & 33 & 35 & & 6 & $4.8 \pm 3.3^{*}$ & $67 \pm 10$ & 19 & 32 & 30 & & 4 & $3.9 \pm 2.6^{*}$ \\
\hline \multicolumn{15}{|c|}{ Pevni et $\mathrm{al}^{6}$} \\
\hline RITA & $18 \dagger \dagger$ & 22 & 38 & 8 & 5 & 8 & $5.8 \pm 3.2 *$ & $18 \dagger \dagger$ & 31 & 54 & 4 & 12 & 8 & $6.05 \pm 3.3^{*}$ \\
\hline RA & $36 \dagger \dagger$ & 36 & 61 & 6 & 15 & 12 & $7.5 \pm 4.1^{*}$ & $22 \dagger \dagger$ & 31 & 52 & 4 & 8 & 8 & $5.90 \pm 3.17^{*}$ \\
\hline \multicolumn{15}{|c|}{${\text { Raja et } \mathrm{al}^{7}}$} \\
\hline RITA & 60 & 11 & 16 & 13 & 8 & 2 & NR & 62 & 12 & 21 & 15 & 7 & 1 & NR \\
\hline RA & 62 & 16 & 31 & 18 & 7 & 1 & & 62 & 15 & 25 & 17 & 7 & 1 & \\
\hline \multicolumn{15}{|c|}{ Ruttmann et al ${ }^{8}$} \\
\hline RITA & $57 \pm 10$ & 10 & 21 & 20 & 33 & 3 & $2.3 \pm 2.6^{*}$ & $57 \pm 10$ & 10 & 21 & 20 & 33 & 3 & $2.3 \pm 2.6^{*}$ \\
\hline RA & $60 \pm 10$ & 14 & 24 & 24 & 20 & 1 & $2.8 \pm 2.3 *$ & $58 \pm 9$ & 10 & 22 & 20 & 33 & 2 & $2.4 \pm 2.5^{*}$ \\
\hline \multicolumn{15}{|c|}{ Schwann et $\mathrm{al}^{9}$} \\
\hline RITA & $60 \pm 10$ & 12 & 15 & $54 \pm 11 \ddagger$ & 6 & NR & NR & $60 \pm 10$ & 14 & 17 & $53 \pm 11 \ddagger$ & 7 & NR & NR \\
\hline RA & $62 \pm 10$ & 25 & 37 & $49 \pm 10 \ddagger$ & 18 & & & $58 \pm 10$ & 13 & 18 & $52 \pm 10 \ddagger$ & 8 & & \\
\hline \multicolumn{15}{|c|}{ Shi et $\mathrm{al}^{10}$} \\
\hline RITA & $60 \pm 10$ & 8 & 13 & 23 & 3 & NR & NR & $63 \pm 9$ & 11 & 19 & 23 & 3 & NR & NR \\
\hline RA & $68 \pm 10$ & 25 & 30 & 27 & 5 & & & $63 \pm 10$ & 11 & 18 & 24 & 4 & & \\
\hline \multicolumn{15}{|c|}{ Tranbaugh et al ${ }^{11}$} \\
\hline RITA & $66 \pm 11$ & 29 & 35 & $46 \pm 15 \ddagger$ & 8 & 3 & NR & $61 \pm 11$ & 23 & 36 & $48 \pm 14$ & 10 & 2 & NR \\
\hline RA & $58 \pm 8$ & 17 & 38 & $48 \pm 13 \ddagger$ & 19 & 2 & & $60 \pm 8$ & 22 & 37 & $47 \pm 14 \ddagger$ & 10 & 2 & \\
\hline \multicolumn{15}{|c|}{ Tsuneyoshi et al ${ }^{12}$} \\
\hline RITA & $68 \pm 8$ & 19 & 55 & 3 & 2 & NR & $1.56 \dagger$ & $68 \pm 10$ & 19 & 53 & 2 & 2 & NR & $1.64 \dagger$ \\
\hline RA & $69 \pm 11$ & 23 & 46 & 2 & 3 & & $1.57 \dagger$ & $68 \pm 10$ & 25 & 45 & 1 & 2 & & $1.61 \dagger$ \\
\hline
\end{tabular}

$S D$, Standard deviation; $D M$, diabetes mellitus; $L V D$, left ventricular dysfunction (different definition adopted); $C O P D$, chronic obstructive pulmonary disease; $R D$, renal failure (different definition adopted); RITA, right internal thoracic artery; $N R$, not reported; $R A$, radial artery. *EuroSCORE. $\dagger$ Society of Thoracic Surgeons score. $\dagger \dagger$ Percentage of patients aged $\geq 75$. †Mean left ventricular ejection fraction.

mortality. When compared with RA, the use of RITA was associated with better survival regardless of the target coronary location, thus supporting previous reports. ${ }^{26,27}$ The main reason for the long-term benefit of RITA might be attributed partially to its higher capacity for nitric oxide release than RA, which could be responsible for the inferior long-term graft patency. ${ }^{28}$ The superiority of RITA over RA in terms of long-term survival is also supported by a recent network meta-analysis of RTC $^{2}$ which found RITA to be associated with a $27 \%$ absolute risk reduction for late ( $>4$ years) functional graft occlusion compared with RA. Of note, we found a significant heterogeneity for late mortality among studies. The different risk profiles of study populations might partially explain such variability. The study by Ruttmann et $\mathrm{al}^{8}$ reported the highest effect size in a relatively younger population (mean age 57 years), with a relatively low prevalence of women $(10 \%)$ and diabetes mellitus $(20 \%)$. At the other extreme is the study by

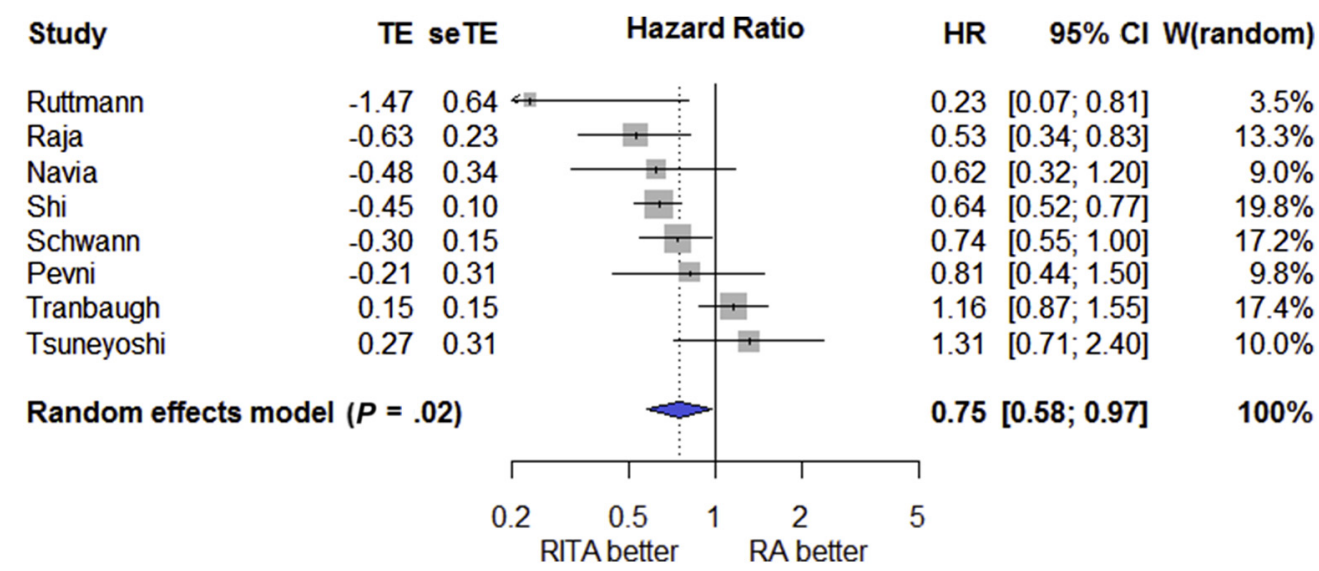

FIGURE 2. Forest plot comparing the effect of right internal thoracic artery (RITA) versus the radial artery (RA) on late mortality across individual studies and by means of pooled estimates. TE, Treatment effect; seTE, standard error; $H R$, hazard ratio; $C I$, confidence interval. 


\section{OPERATIVE MORTALITY}

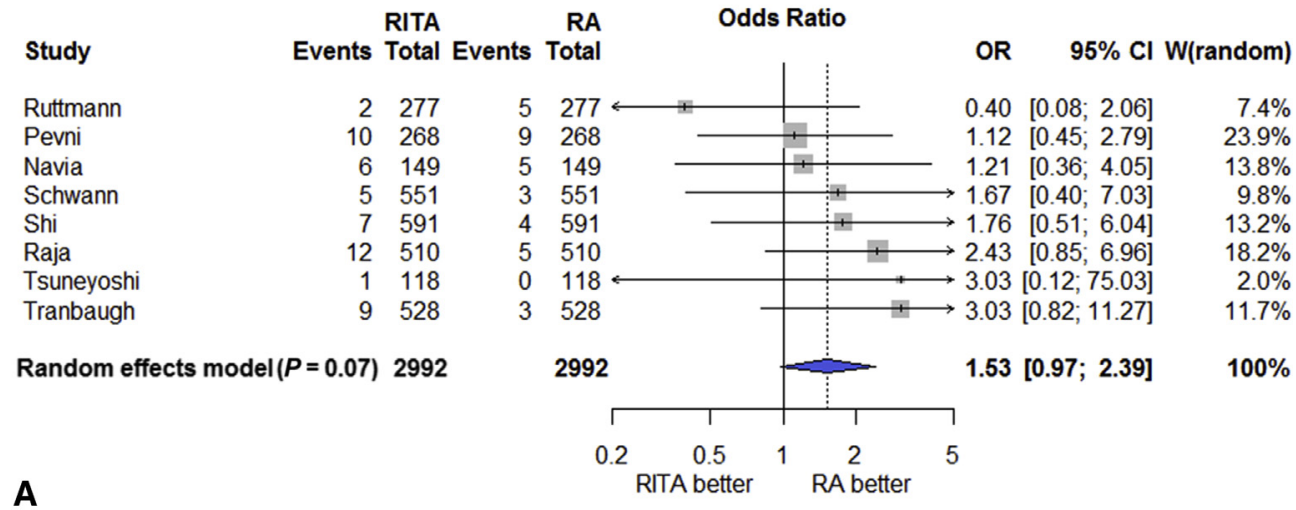

\section{STERNAL WOUND COMPLICATION}

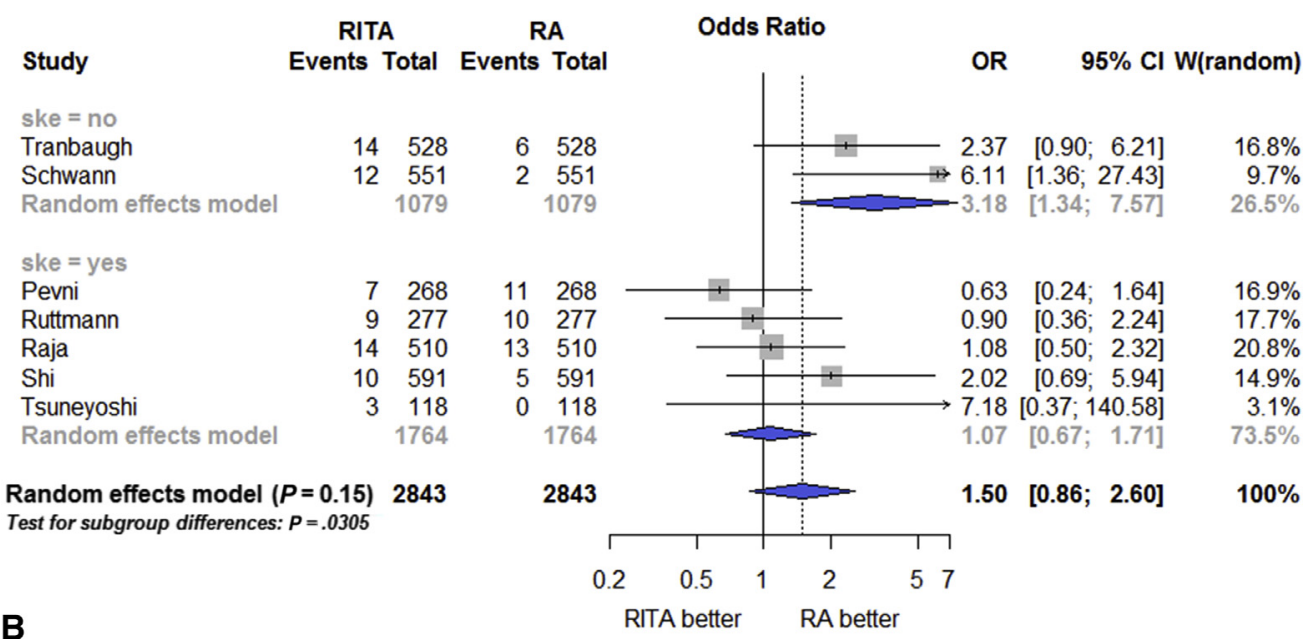

\section{REPEAT REVASCULARIZATION}

$\begin{array}{lrr}\text { Study } & \text { TE seTE } \\ \text { Ruttmann } & -1.95 & 0.53 \\ \text { Navia } & -0.92 & 0.41 \\ \text { Raja } & -0.42 & 0.20 \\ & & \\ \text { Random effects model }(\boldsymbol{P}=\mathbf{0 . 0 2}) & \end{array}$

C

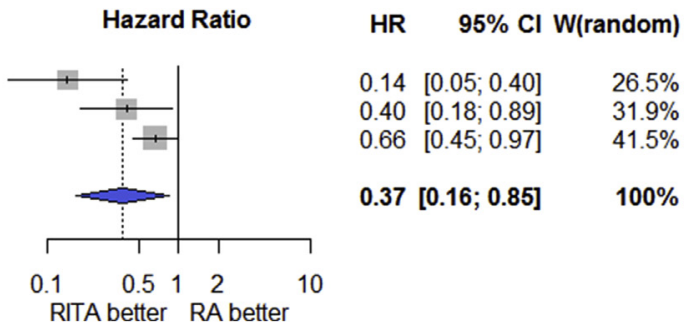

FIGURE 3. Forest plot comparing the effect of right internal thoracic artery (RITA) versus the radial artery $(R A)$ on operative mortality (A), incidence of sternal wound complication (B), and repeat revascularization $(\mathrm{C})$ across individual studies and by means of pooled estimates. $O R$, Odds ratio; $C I$, confidence interval; TE, treatment effect; seTE, standard error.

Tsuneyoshi et al, ${ }^{12}$ which reported the lowest effect size in a relatively older population (mean age 68 years), with a higher prevalence of women $(\sim 20 \%)$ and diabetes mellitus $(\sim 50 \%)$. Also, Tranbaugh et al ${ }^{11}$ failed to show any benefit from RITA. Of note, in their study the prevalence of women and diabetes was relatively high $(\sim 23 \%$ and $\sim 36 \%$, respectively). It has been proposed that low-risk patients with prolonged life expectation are more likely to present a survival benefit from the use of RITA. In fact, its beneficial effect on survival may be delayed by as much as 7 to 10 years but persists beyond that time; however, it may be less beneficial in older patients with coexistent morbidities 


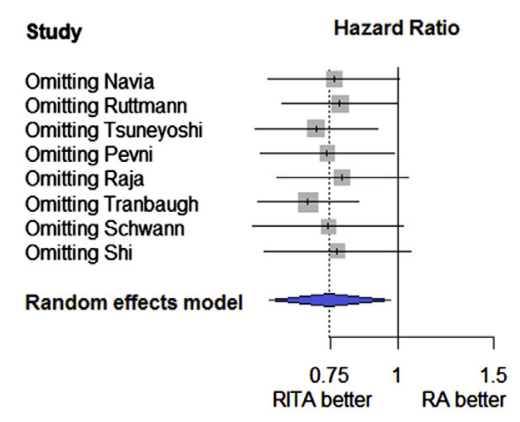

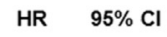

0.76 [0.58; 1.01]

$0.78[0.61 ; 1.00]$

0.71 [0.55; 0.92

$0.74[0.56 ; 0.98]$

$0.79[0.60 ; 1.04]$

$0.68[0.55 ; 0.85]$

$0.75[0.54 ; 1.03]$
$0.77[0.57 ; 1.06]$

$0.75[0.58 ; 0.97]$
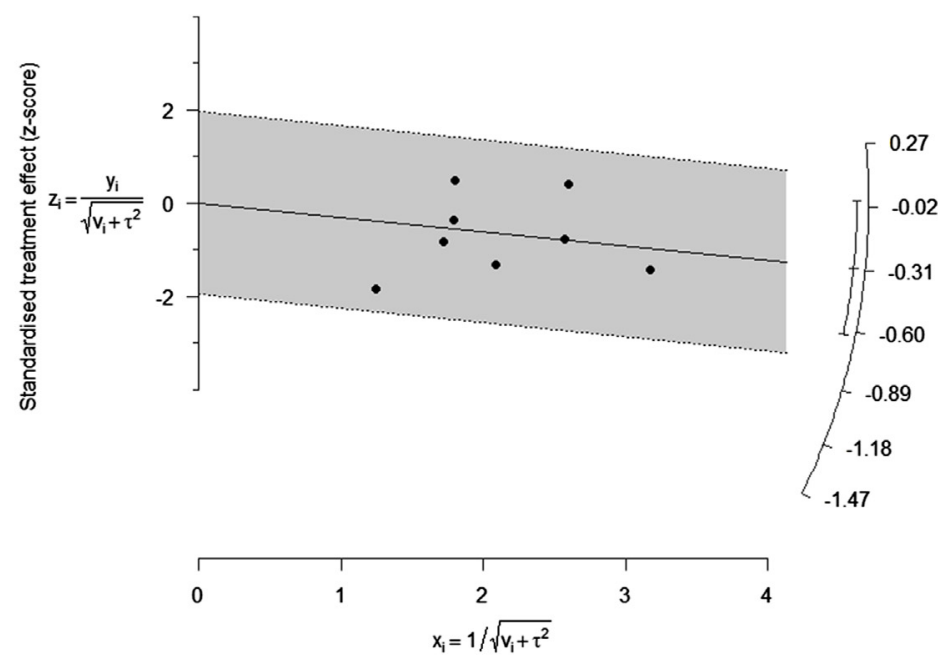

Inverse of standard error

FIGURE 4. Forest plot of the leave-one-out sensitivity analysis (left) and the radial plot (right) comparing the effect of right internal thoracic artery (RITA) versus radial artery $(R A)$ on late mortality. $H R$, Hazard ratio; $C I$, confidence interval.

and limited life expectancy. ${ }^{29-31}$ Another possible explanation for the heterogeneity among studies is the use of different surgical techniques. In the study by Ruttmann et al, ${ }^{8}$ RITA was preferentially used as in situ graft through the transverse sinus, whereas in the study by Tranbaugh et $a l,{ }^{11}$ it was used as a Y graft in most cases. The latest configuration is more technically demanding and leads to higher rates of competitive flow, which can potentially increase graft failure, ${ }^{32}$ although no definitive data are available to confirm this finding. ${ }^{33}$

We found that when harvested as a skeletonized conduit, the use of RITA was associated with a similar rate of postoperative sternal complications observed in those receiving RA. However, when harvested as a pedicle, RITA was associated with a 3-fold increased risk of sternal wound infection. Skeletonized harvesting has been consistently demonstrated to minimize the risk of sternal wound complications in patients receiving bilateral internal thoracic arteries, ${ }^{34-36}$ in particular in those with diabetes mellitus. ${ }^{35,36}$

The present analysis has intrinsic limitations. Propensity matching can adjust only for measurable and included variables, and we cannot exclude a selection bias based on nonmeasurable "eye-ball" variables (with RITA reserved for healthier patients). Moreover, the use of propensity matching increases the internal validity of studies and limits the ability to generalize findings. Only $39 \%$ of the overall study population in the present meta-analysis was included in the propensity-matched groups. In particular, data on diabetic patients were not reported separately. Therefore, we could not draw conclusions on the superiority of RITA in such a high-risk subgroup. Finally, different authors used different PSM models so that the homogeneity of the included populations cannot be regarded as optimal. In particular, 3 of 8 studies included in the main analysis ${ }^{5,9,12}$ did not specify whether the methods used for comparison accounted for matched pairs, ${ }^{37}$ and only 1 study $^{11}$ tested the non-violation of proportional hazard assumption.

In conclusion, the present PSM data meta-analysis suggests that, compared with RA, the use of RITA can be associated with superior long-term survival and a lower incidence of repeat revascularization. However, this benefit might be less relevant in high-risk subgroups such as older, female, and diabetic patients. In particular, specific data on diabetic populations are not available. In this group, RA should be considered as a valid option, taking into account the increased risk of sternal wound complications in the case of harvesting bilateral internal thoracic arteries. Skeletonized harvesting should be strongly recommended when RITA is preferred over RA, because this technique minimizes the risk of sternal wound complication.

\section{References}

1. Tranbaugh RF, Lucido DJ, Dimitrova KR, Hoffman DM, Geller CM, Dincheva GR, et al. Multiple arterial bypass grafting should be routine. J Thorac Cardiovasc Surg. 2015;150:1537-45.

2. Benedetto U, Raja SG, Albanese A, Amrani M, Biondi-Zoccai G, Frati G. Searching for the second best graft for coronary artery bypass surgery: a network metaanalysis of randomized controlled trials. Eur J Cardiothorac Surg. 2015;47:59-65.

3. Buxton BF, Raman JS, Ruengsakulrach P, Gordon I, Rosalion A, Bellomo R, et al. Radial artery patency and clinical outcomes: five-year interim results of a randomized trial. J Thorac Cardiovasc Surg. 2003;125:1363-71.

4. Lonjon G, Boutron I, Trinquart L, Ahmad N, Aim F, Nizard R, et al. Comparison of 100 treatment effect estimates from prospective nonrandomized studies with 101 propensity score analysis and randomized controlled trials of surgical procedures. Ann Surg. 2014;259:18-25.

5. Navia D, Vrancic M, Piccinini F, Camporrotondo M, Thierer J, Gil C, et al. Is the second internal thoracic artery better than the radial artery in total arterial offpump coronary artery bypass grafting? A propensity score-matched follow-up study. J Thorac Cardiovasc Surg. 2014;147:632-8.

6. Pevni D, Mohr R, Paz Y, Kramer A, Ben-Gal Y, Nesher N, et al. Long-term outcome of revascularization with composite T-grafts: is bilateral mammary grafting better than single mammary and radial artery grafting? J Thorac Cardiovasc Surg. 2016;151:1311-9. 
7. Raja SG, Benedetto U, Jothidasan A, Jujjavarapu RK, Ukwu UF, De Robertis F, et al. Right internal mammary artery versus radial artery as second arterial conduit in coronary artery bypass grafting: a case-control study of 1526 patients. Int J Surg. 2015;16:183-9.

8. Ruttmann E, Fischler N, Sakic A, Chevtchik O, Alber H, Schistek R, et al. Second internal thoracic artery versus radial artery in coronary artery bypass grafting: a long-term, propensity score-matched follow-up study. Circulation. 2011; 124:1321-9.

9. Schwann TA, Hashim SW, Badour S, Obeid M, Engoren M, Tranbaugh RF, et al. Equipoise between radial artery and right internal thoracic artery as the second arterial conduit in left internal thoracic artery-based coronary artery bypass graft surgery: a multi-institutional study. Eur J Cardiothorac Surg. 2016;49:188-95.

10. Shi WY, Hayward PA, Tatoulis J, Rosalion A, Newcomb AE, Fuller JA, et al. Are all forms of total arterial revascularization equal? A comparison of single versus bilateral internal thoracic artery grafting strategies. J Thorac Cardiovasc Surg. 2015;150:1526-34.

11. Tranbaugh RF, Dimitrova KR, Lucido DJ, Hoffman DM, Dincheva GR, Geller CM, et al. The second best arterial graft: a propensity analysis of the radial artery versus the free right internal thoracic artery to bypass the circumflex coronary artery. J Thorac Cardiovasc Surg. 2014;147:133-40.

12. Tsuneyoshi H, Komiya T, Shimamoto T, Sakai J, Hiraoka T, Kawashima T, et al. The second best arterial graft to the left coronary system in off-pump bypass surgery: a propensity analysis of the radial artery with a proximal anastomosis to the ascending aorta versus the right internal thoracic artery. Gen Thorac Cardiovasc Surg. 2015;63:335-42.

13. Liberati A, Altman DG, Tetzlaff J, Mulrow C, Gøtzsche PC, Ioannidis JPA, et al. The PRISMA statement for reporting systematic reviews and meta-analyses of studies that evaluate health care interventions: explanation and elaboration. Ann Intern Med. 2009; 151:W-65-94.

14. Wells GA, Shea B, O'Connell D, Peterson J, Welch V, Tugwell P. The Newcastle-Ottawa Scale (NOS) for assessing the quality of nonrandomized studies in meta-analysis. In: 3rd Symposium on Systematic Reviews: Beyond the Basics; July 3-5. Oxford 2000.

15. Nilsson J, Algotsson L, Höglund P, Lührs C, Brandt J. Early mortality in coronary bypass surgery: the EuroSCORE versus The Society of Thoracic Surgeons risk algorithm. Ann Thorac Surg. 2004;77:1235-9.

16. Williamson PR, Tudur Smith C, Hutton JL, Marson AG. Aggregate data metaanalysis with time-to-event outcomes. Stat Med. 2002;21:3337-51.

17. DerSimonian R, Laird N. Meta-analysis in clinical trials. Control Clin Trials. 1986; 7:177-88.

18. Higgins JP, Thompson SG, Deeks JJ, Altman DG. Measuring inconsistency in meta-analyses. BMJ. 2003;327:557-66.

19. Song F, Khan KS, Dinnes J, Sutton AJ. Asymmetric funnel plots and publication bias in meta-analyses of diagnostic accuracy. Int J Epidemiol. 2002;31:88-95.

20. Borger MA, Cohen G, Buth KJ, Rao V, Bozinovski J, Liaghati-Nasseri N, et al. Multiple arterial grafts. Radial versus right internal thoracic arteries. Circulation. 1998;98:II7-14.

21. Calafiore AM, Di Mauro M, D’Alessandro S, Teodori G, Vitolla G, Contini M, et al. Revascularization of the lateral wall: long-term angiographic and clinical results of radial artery versus right internal thoracic artery grafting. J Thorac Cardiovasc Surg. 2002;123:225-31.

22. Caputo M, Reeves B, Marchetto G, Mahesh B, Lim K, Angelini GD. Radial versus right internal thoracic artery as a second arterial conduit for coronary surgery: early and midterm outcomes. J Thorac Cardiovasc Surg. 2003;126:39-47.
23. Lemma M, Gelpi G, Mangini A, Vanelli P, Carro C, Condemi A, et al. Myocardial revascularization with multiple arterial grafts: comparison between the radial artery and the right internal thoracic artery. Ann Thorac Surg. 2001;71: 1969-73.

24. Miana LA, Lima DS, Whitaker JF, Passos PH, Loures JB, Miana AA. Immediate results of right internal thoracic artery and radial artery as the second arterial graft in myocardial revascularization. Rev Bras Cir Cardiovasc. 2007;22:60-7.

25. Vicol C, Raab S, Beyer M, Reichart B. Myocardial revascularization using the arterial T graft: which conduit should be chosen for the free graft? Heart Surg Forum. 2003:6:353-7.

26. Sabik JF III, Stockins A, Nowicki ER, Blackstone EH, Houghtaling PL, Lytle BW, et al. Does location of the second internal thoracic artery graft influence outcome of coronary artery bypass grafting? Circulation. 2008;118:S210-5.

27. Kurlansky PA, Traad EA, Dorman MJ, Galbut DL, Zucker M, Ebra G. Location of the second internal mammary artery graft does not influence outcome of coronary artery bypass grafting. Ann Thorac Surg. 2011;91:1378-83.

28. He GW, Liu ZG. Comparison of nitric oxide release and endothelium-derived hyperpolarizing factor-mediated hyperpolarization between human radial and internal mammary arteries. Circulation. 2001;104:I344-9.

29. Benedetto U, Amrani M, Raja SG. Guidance for the use of bilateral internal thoracic arteries according to survival benefit across age groups. J Thorac Cardiovasc Surg. 2014;148:2706-11.

30. Kieser TM, Lewin AM, Graham MM, Martin BJ, Galbraith PD, Rabi DM, et al Outcomes associated with bilateral internal thoracic artery grafting: the importance of age. Ann Thorac Surg. 2011;92:1269-75.

31. Mohammadi S, Dagenais F, Doyle D, Mathieu P, Baillot R, Charbonneau E, et al Age cut-off for the loss of benefit from bilateral internal thoracic artery grafting. Eur J Cardiothorac Surg. 2008:33:977-82.

32. Calafiore AM, Contini M, Vitolla G, Di Mauro M, Mazzei V, Teodori G, et al Bilateral internal thoracic artery grafting: long-term clinical and angiographic results of in situ versus Y grafts. J Thorac Cardiovasc Surg. 2000;120:990-6.

33. Raja SG, Benedetto U, Husain M, Soliman R, De Robertis F, Amrani M. Does grafting of the left anterior descending artery with the in situ right internal thoracic artery have an impact on late outcomes in the context of bilateral internal thoracic artery usage? J Thorac Cardiovasc Surg. 2014;148:1275-81.

34. Kieser TM, Rose MS, Aluthman U, Montgomery M, Louie T, Belenkie I. Toward zero: deep sternal wound infection after 1001 consecutive coronary artery bypass procedures using arterial grafts: implications for diabetic patients. J Thorac Cardiovasc Surg. 2014;148:1887-95.

35. Raza S, Sabik JF III, Masabni K, Ainkaran P, Lytle BW, Blackstone EH. Surgica revascularization techniques that minimize surgical risk and maximize late survival after coronary artery bypass grafting in patients with diabetes mellitus. J Thorac Cardiovasc Surg. 2014;148:1257-64.

36. Benedetto U, Altman GD, Gerry D, Gray A, Lees B, Pawlaczyk R, et al. Pedicled and skeletonized single and bilateral internal mammary artery grafts and the incidence of sternal wound complications: Insights from the Arterial Revascularization Trial (ART). J Thorac Cardiovasc Surg. 2016;152:270-6.

37. Austin PC. A tutorial and case study in propensity score analysis: an application to estimating the effect of in-hospital smoking cessation counseling on mortality. Multivariate Behav Res. 2011;46:119-51.

Key Words: propensity score matching, right internal thoracic artery, radial artery 


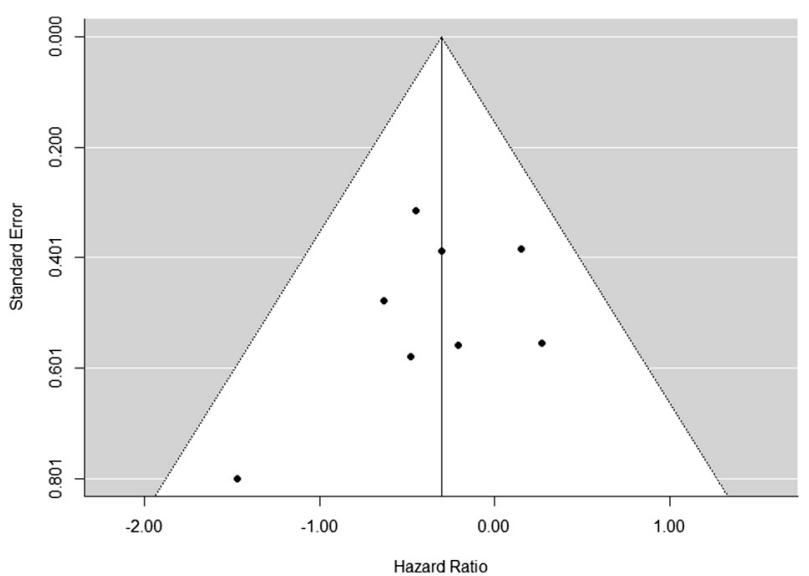

FIGURE E1. Funnel plot comparing the effect of right internal thoracic artery (RITA) versus radial artery (RA) on late mortality.
OPERATIVE MORTALITY

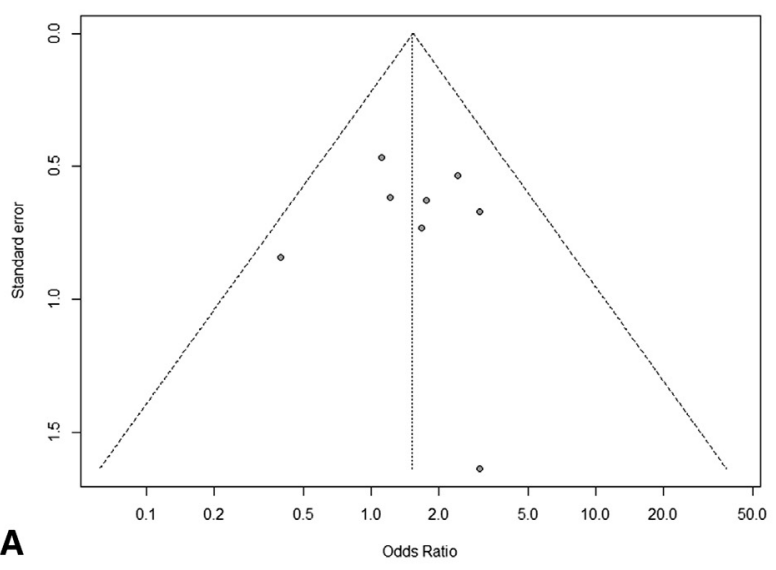

STERNAL WOUND COMPLICATION

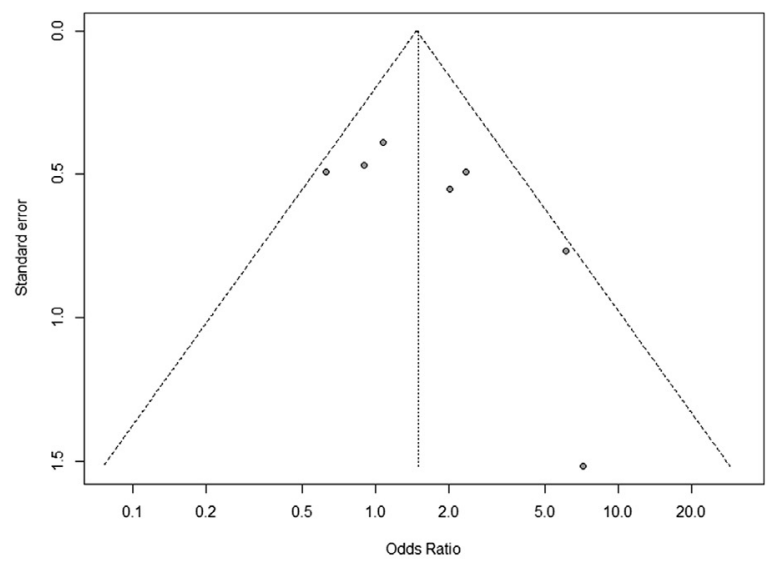

B

REPEAT REVASCULARIZATION

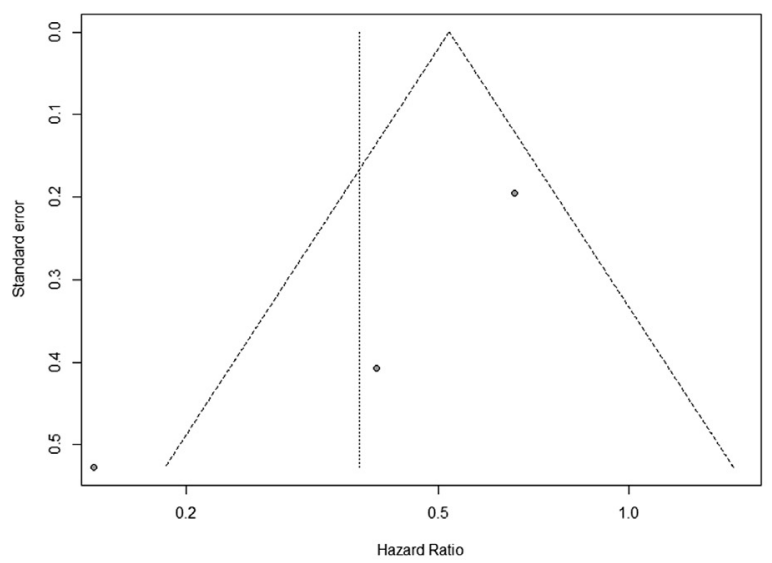

FIGURE E2. Funnel plot comparing the effect of right internal thoracic artery (RITA) versus radial artery (RA) on operative mortality (A), incidence of sternal wound complication (B), and repeat revascularization (C). 


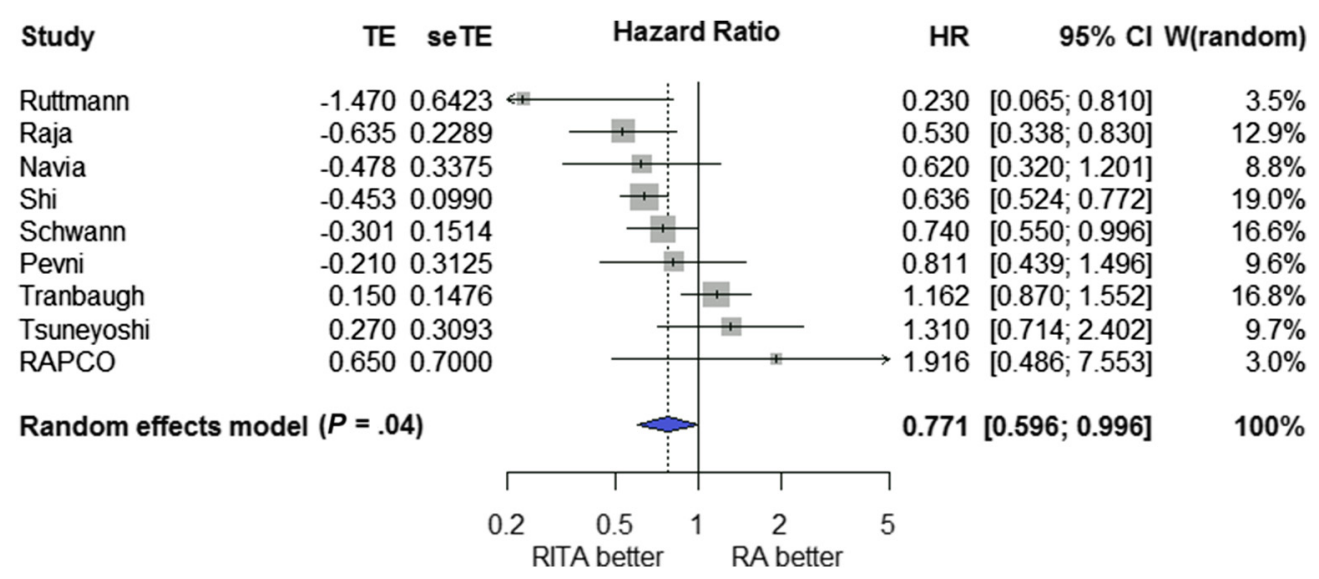

FIGURE E3. Forest plot comparing the effect of right internal thoracic artery (RITA) versus radial artery $(R A)$ on operative mortality in propensity matching studies and the RAPCO trial across individual studies and by means of pooled estimates. TE, Treatment effect; seTE, standard error; $H R$, hazard ratio; $C I$, confidence interval.

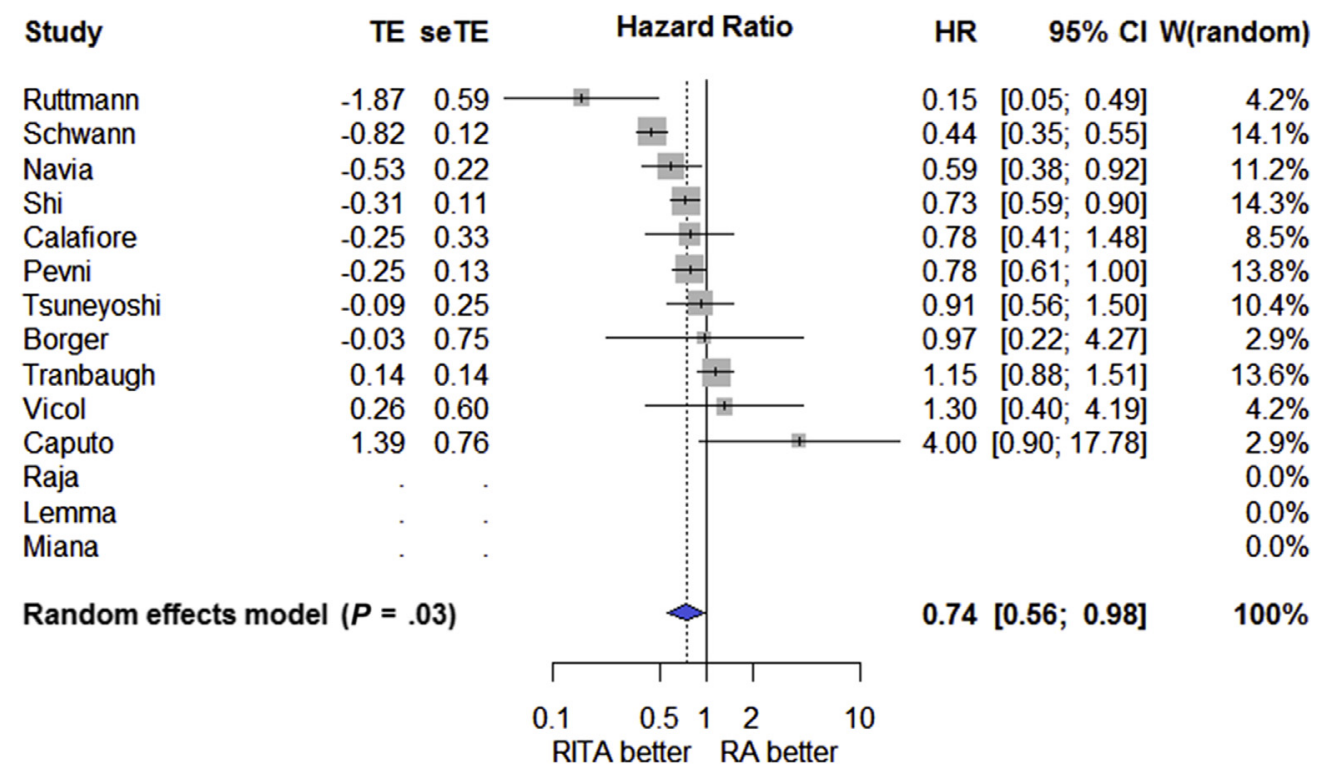

FIGURE E4. Forest plot comparing the effect of right internal thoracic artery (RITA) versus radial artery $(R A)$ on operative mortality in all unmatched populations. TE, Treatment effect; seTE, standard error; $H R$, hazard ratio; $C I$, confidence interval. 


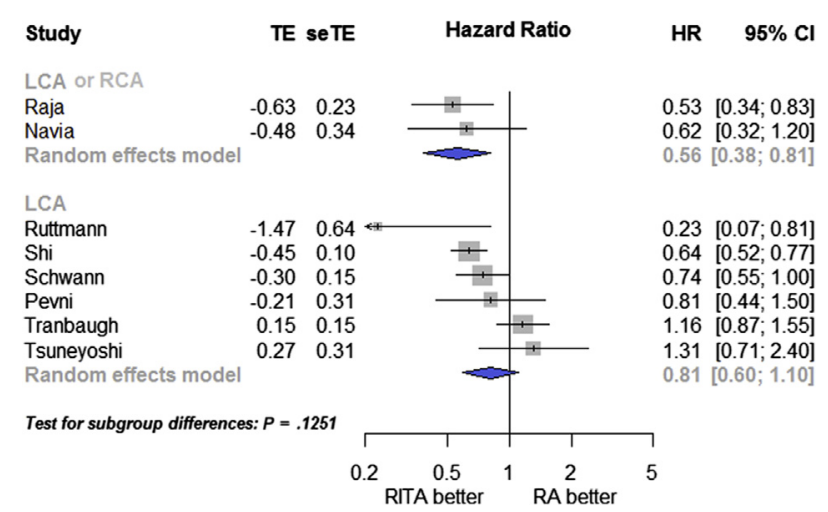

FIGURE E5. Forest plot comparing the effect of right internal thoracic artery $(R I T A)$ versus radial artery $(R A)$ on operative mortality according to the target. $L C A$, Left coronary artery; $R C A$, right coronary artery; $T E$, treatment effect; seTE, standard error; $H R$, hazard ratio; $C I$, confidence interval. 
TABLE E1. PRISMA 2009 checklist

\begin{tabular}{|c|c|c|c|}
\hline Section/topic & Number & Checklist item & Reported on page number \\
\hline \multicolumn{4}{|l|}{ TITLE } \\
\hline Title & 1 & Identify the report as a systematic review, meta-analysis, or both & 1 \\
\hline \multicolumn{4}{|l|}{ ABSTRACT } \\
\hline Structured summary & 2 & $\begin{array}{l}\text { Provide a structured summary including, as applicable: background; } \\
\text { objectives; data sources; study eligibility criteria, participants, } \\
\text { and interventions; study appraisal and synthesis methods; results; } \\
\text { limitations; conclusions and implications of key findings; } \\
\text { systematic review registration number }\end{array}$ & 3 \\
\hline \multicolumn{4}{|l|}{ INTRODUCTION } \\
\hline Rationale & 3 & $\begin{array}{l}\text { Describe the rationale for the review in the context of what is already } \\
\text { known }\end{array}$ & 8 \\
\hline Objectives & 4 & $\begin{array}{l}\text { Provide an explicit statement of questions being addressed with } \\
\text { reference to participants, interventions, comparisons, outcomes, } \\
\text { and study design (PICOS) }\end{array}$ & 8 \\
\hline \multicolumn{4}{|l|}{ METHODS } \\
\hline Protocol and registration & 5 & $\begin{array}{l}\text { Indicate if a review protocol exists, if and where it can be accessed } \\
\text { (eg, Web address), and, if available, provide registration } \\
\text { information including registration number }\end{array}$ & None \\
\hline Eligibility criteria & 6 & $\begin{array}{l}\text { Specify study characteristics (eg, PICOS, length of follow-up) and } \\
\text { report characteristics (eg, years considered, language, } \\
\text { publication status) used as criteria for eligibility, giving } \\
\text { rationale }\end{array}$ & 9 \\
\hline Information sources & 7 & $\begin{array}{l}\text { Describe all information sources (eg, databases with dates of } \\
\text { coverage, contact with study authors to identify additional } \\
\text { studies) in the search and date last searched }\end{array}$ & 9 \\
\hline Search & 8 & $\begin{array}{l}\text { Present full electronic search strategy for at least } 1 \text { database, } \\
\text { including any limits used, such that it could be repeated }\end{array}$ & 9 \\
\hline Study selection & 9 & $\begin{array}{l}\text { State the process for selecting studies (ie, screening, eligibility, } \\
\text { included in systematic review, and, if applicable, included in } \\
\text { the meta-analysis) }\end{array}$ & 9 \\
\hline Data collection process & 10 & $\begin{array}{l}\text { Describe method of data extraction from reports (eg, piloted forms, } \\
\text { independently, in duplicate) and any processes for obtaining } \\
\text { and confirming data from investigators }\end{array}$ & 9,10 \\
\hline Data items & 11 & $\begin{array}{l}\text { List and define all variables for which data were sought (eg, PICOS, } \\
\text { funding sources) and any assumptions and simplifications } \\
\text { made }\end{array}$ & 9 \\
\hline Risk of bias in individual studies & 12 & $\begin{array}{l}\text { Describe methods used for assessing risk of bias of individual } \\
\text { studies (including specification of whether this was done at the } \\
\text { study or outcome level), and how this information is to be used } \\
\text { in any data synthesis }\end{array}$ & 9 \\
\hline Summary measures & 13 & $\begin{array}{l}\text { State the principal summary measures (eg, risk ratio, difference in } \\
\text { means) }\end{array}$ & 10,11 \\
\hline Synthesis of results & 14 & $\begin{array}{l}\text { Describe the methods of handling data and combining results of } \\
\text { studies, if done, including measures of consistency }\left(\mathrm{eg}, I^{2}\right) \text { for } \\
\text { each meta-analysis }\end{array}$ & 10,11 \\
\hline Risk of bias across studies & 15 & $\begin{array}{l}\text { Specify any assessment of risk of bias that may affect the cumulative } \\
\text { evidence (eg, publication bias, selective reporting within } \\
\text { studies) }\end{array}$ & 10,11 \\
\hline Additional analyses & 16 & $\begin{array}{l}\text { Describe methods of additional analyses (eg, sensitivity or subgroup } \\
\text { analyses, meta-regression), if done, indicating which were pre- } \\
\text { specified }\end{array}$ & 10,11 \\
\hline \multicolumn{4}{|l|}{ RESULTS } \\
\hline Study selection & 17 & $\begin{array}{l}\text { Give numbers of studies screened, assessed for eligibility, and } \\
\text { included in the review, with reasons for exclusions at each } \\
\text { stage, ideally with a flow diagram }\end{array}$ & 12 \\
\hline
\end{tabular}

\section{INTRODUCTION}

Objectives

THODS 
TABLE E1. Continued

\begin{tabular}{|c|c|c|c|}
\hline Section/topic & Number & Checklist item & Reported on page number \\
\hline Study characteristics & 18 & $\begin{array}{l}\text { For each study, present characteristics for which data were extracted } \\
\text { (eg, study size, PICOS, follow-up period) and provide the } \\
\text { citations }\end{array}$ & 12 \\
\hline Risk of bias within studies & 19 & $\begin{array}{l}\text { Present data on risk of bias of each study and, if available, any } \\
\text { outcome level assessment (see item 12) }\end{array}$ & 12 \\
\hline Results of individual studies & 20 & $\begin{array}{l}\text { For all outcomes considered (benefits or harms), present, for each } \\
\text { study: (1) simple summary data for each intervention group and } \\
\text { (2) effect estimates and confidence intervals, ideally with a } \\
\text { forest plot }\end{array}$ & $12-14$ \\
\hline Synthesis of results & 21 & $\begin{array}{l}\text { Present results of each meta-analysis done, including confidence } \\
\text { intervals and measures of consistency }\end{array}$ & $12-14$ \\
\hline Risk of bias across studies & 22 & $\begin{array}{l}\text { Present results of any assessment of risk of bias across studies (see } \\
\text { item 15) }\end{array}$ & $12-14$ \\
\hline Additional analysis & 23 & $\begin{array}{l}\text { Give results of additional analyses, if done (eg, sensitivity or } \\
\text { subgroup analyses, meta-regression [see item 16]) }\end{array}$ & 14 \\
\hline \multicolumn{4}{|l|}{ DISCUSSION } \\
\hline Summary of evidence & 24 & $\begin{array}{l}\text { Summarize the main findings including the strength of evidence for } \\
\text { each main outcome; consider their relevance to key groups (eg, } \\
\text { healthcare providers, users, and policy makers) }\end{array}$ & 15 \\
\hline Limitations & 25 & $\begin{array}{l}\text { Discuss limitations at study and outcome level (eg, risk of bias), and } \\
\text { at review-level (eg, incomplete retrieval of identified research, } \\
\text { reporting bias) }\end{array}$ & 15,16 \\
\hline Conclusions & 26 & $\begin{array}{l}\text { Provide a general interpretation of the results in the context of other } \\
\text { evidence, and implications for future research }\end{array}$ & $16-18$ \\
\hline \multicolumn{4}{|l|}{ FUNDING } \\
\hline Funding & 27 & $\begin{array}{l}\text { Describe sources of funding for the systematic review and other } \\
\text { support (eg, supply of data); role of funders for the systematic } \\
\text { review }\end{array}$ & 1 \\
\hline
\end{tabular}

From: Moher D, Liberati A, Tetzlaff J, Altman DG, The PRISMA Group. Preferred reporting items for systematic reviews and meta-analyses: the PRISMA statement. PLoS Med. 2009;6:e1000097. 
TABLE E2. Overview of non-propensity score-matched studies excluded from the primary analysis

\begin{tabular}{|c|c|c|c|c|c|c|c|c|c|}
\hline Study & $\begin{array}{c}\text { Year of } \\
\text { publication }\end{array}$ & Study design & Center & $\begin{array}{l}\text { Study } \\
\text { period }\end{array}$ & RITA & RA & Target & $\begin{array}{c}\text { Mean } \\
\text { follow-up (mo) }\end{array}$ & Conclusions \\
\hline Hayward et al ${ }^{3}$ & 2007 & $\mathrm{RCT}$ & $\begin{array}{c}\text { Australia } \\
\text { (Austin } \\
\text { Hospital) }\end{array}$ & 1996-2002 & 140 & 145 & LCA/RCA & 60 & $\begin{array}{l}\text { These } 2 \text { arterial conduits } \\
\text { may yield equivalent } \\
\text { clinical outcomes at } 5 \\
\text { or more years }\end{array}$ \\
\hline Borger et $\mathrm{al}^{20}$ & 1998 & $\begin{array}{l}\text { Observational } \\
\text { (no adjustment) }\end{array}$ & Canada & 1989-1996 & 132 & 171 & LCA/RCA & NA & $\begin{array}{l}\text { Sternal complication: } \\
\text { RITA, } 5.3 \% \text { vs RA, } \\
0.6 \% ; P=.01 \\
\text { Comparable } 3 \text { y survival } \\
\text { (both } 98 \% ; P=.88 \text { ) }\end{array}$ \\
\hline Calafiore et $\mathrm{al}^{21}$ & 2002 & $\begin{array}{l}\text { Observational (no } \\
\text { adjustment) }\end{array}$ & Italy & 1992-1996 & 149 & 139 & LCA only & $77 \pm 16$ & $\begin{array}{l}\text { Comparable incidence of } \\
\text { sternal complication: } \\
\text { RA, } 4.3 \% \text { vs RITA, } \\
2.7 \%(P=.6) ; 8 \text { y } \\
\text { survival } 86.7 \% \text { in RA } \\
\text { group vs } 89.6 \% \text { in } \\
\text { RITA group }(P=.4)\end{array}$ \\
\hline Caputo et $\mathrm{al}^{22}$ & 2003 & $\begin{array}{l}\text { Observational } \\
\text { (adjusted } \\
\text { Cox model) }\end{array}$ & $\begin{array}{l}\text { United } \\
\text { Kingdom }\end{array}$ & $1996-2001$ & 336 & 325 & LCA/RCA & RITA, 21; RA, 18 & $\begin{array}{c}18 \text { mo survival RITA, } \\
98.4 \% \text { vs RA, } 99.7 \% \\
\text { HR, } 0.25 ; 95 \% \text { CI, } \\
0.06-1.10 ; P=.07\end{array}$ \\
\hline Lemma et $\mathrm{al}^{23}$ & 2001 & $\begin{array}{l}\text { Observational } \\
\text { (no adjustment) }\end{array}$ & Italy & $1999-2000$ & 94 & 156 & LCA/RCA & $8 \pm 4$ & $\begin{array}{l}\text { Superficial sternal wound } \\
\text { infection greater in } \\
\text { RITA group }(6.3 \% \text { vs } \\
1.3 \% ; P=\mathrm{ns}) ; \text { the } \\
\text { probability of survival } \\
\text { was similar }(P=\mathrm{ns})\end{array}$ \\
\hline Miana et $\mathrm{al}^{24}$ & 2007 & $\begin{array}{l}\text { Observational } \\
\qquad \text { (no adjustment) }\end{array}$ & Brazil & 2003-2006 & 20 & 38 & LCA/RCA & NA & $\begin{array}{c}\text { Mediastinitis was not seen } \\
\text { in this series of patients. } \\
\text { No follow-up available }\end{array}$ \\
\hline Vicol et $\mathrm{al}^{25}$ & 2003 & $\begin{array}{l}\text { Observational (no } \\
\text { adjustment) }\end{array}$ & Germany & $1997-2001$ & 129 & 84 & Not reported & $35 \pm 28$ & $\begin{array}{c}\text { Mediastinitis RITA, } 0.8 \% \\
\text { vs RA, } 1.2 \% P=\mathrm{ns} ; \\
\text { late mortality RITA, } \\
6.9 \% \text { vs RA, } 5.3 \%\end{array}$ \\
\hline
\end{tabular}

$\overline{R I T A}$, Right internal thoracic artery; $R A$, radial artery; $R C T$, randomized controlled trial; $L C A$, left coronary artery; $R C A$, right coronary artery; $N A$, not applicable; $H R$, hazard ratio; $C I$, confidence interval; $n s$, not significant. 
TABLE E3. Pre-treatment variables included for propensity score matching

\begin{tabular}{|c|c|}
\hline Study & Variables \\
\hline Navia et $\mathrm{al}^{5}$ & $\begin{array}{l}\text { Age } \\
\text { Male } \\
\text { Diabetes mellitus } \\
\text { Left ventricular function } \\
\text { EuroSCORE } \\
\text { Preoperative renal dysfunction } \\
\text { Aortic calcification } \\
\text { Prior coronary surgery } \\
\text { Preoperative hematocrit } \\
\text { Non-elective surgery } \\
\text { Number of vessel disease } \\
\text { Left main disease }\end{array}$ \\
\hline Ruttman et $\mathrm{al}^{8}$ & $\begin{array}{l}\text { Male } \\
\text { Age } \\
\text { Body mass index } \\
\text { Smoker (active or previous) } \\
\text { Diabetes mellitus } \\
\text { Chronic obstructive pulmonary disease } \\
\text { Preoperative renal dysfunction } \\
\text { Peripheral arterial disease } \\
\text { Cerebrovascular disease } \\
\text { Previous percutaneous coronary intervention } \\
\text { Left ventricular function } \\
\text { Isolated left main stenosis } \\
\text { Logistic EuroSCORE }\end{array}$ \\
\hline Tsuneyoshi et al $^{12}$ & $\begin{array}{l}\text { Age } \\
\text { Male } \\
\text { Body mass index } \\
\text { Diabetes mellitus } \\
\text { Hypertension } \\
\text { Hyperlipidemia } \\
\text { Chronic obstructive pulmonary disease } \\
\text { Estimated glomerular filtration rate } \\
\text { Previous myocardial infarction } \\
\text { Peripheral arterial disease } \\
\text { Left ventricular function } \\
\text { Mitral regurgitation more than mild } \\
\text { SYNTAX score } \\
\text { STS score }\end{array}$ \\
\hline Pevni et $\mathrm{al}^{6}$ & $\begin{array}{l}\text { Age } \\
\text { Female } \\
\text { Non-insulin-dependent diabetes mellitus } \\
\text { Insulin-dependent diabetes mellitus } \\
\text { Diabetes mellitus + end organ damage } \\
\text { Peripheral vascular disease } \\
\text { Chronic obstructive pulmonary disease } \\
\text { Congestive heart failure } \\
\text { Chronic renal failure } \\
\text { Recent myocardial infarction } \\
\text { Old myocardial infarction } \\
\text { Acute myocardial infarction } \\
\text { Left ventricular function } \\
\text { Preoperative intra-aortic balloon pump } \\
\text { Emergency }\end{array}$ \\
\hline
\end{tabular}

TABLE E3. Continued

\begin{tabular}{|c|c|}
\hline Study & Variables \\
\hline \multirow{13}{*}{ Raja et $\mathrm{al}^{7}$} & Repeat operation \\
\hline & Unstable angina \\
\hline & Prior percutaneous coronary intervention \\
\hline & Left main \\
\hline & Number of vessel disease \\
\hline & EuroSCORE \\
\hline & Time of operation \\
\hline & Propensity score distance \\
\hline & Age \\
\hline & Female \\
\hline & New York Heart Association class \\
\hline & Congestive heart failure \\
\hline & Prior myocardial infarction \\
\hline \multirow{37}{*}{ Tranbaugh et $\mathrm{al}^{11}$} & Previous percutaneous coronary intervention \\
\hline & Hypercholesterolemia \\
\hline & Hypertension \\
\hline & Current smoking \\
\hline & Chronic obstructive pulmonary disease \\
\hline & Cerebrovascular accident \\
\hline & Peripheral vascular disease \\
\hline & History of atrial fibrillation \\
\hline & Left main stem disease \\
\hline & Left ventricular function \\
\hline & Non-elective surgery \\
\hline & Renal impairment \\
\hline & Diabetes mellitus \\
\hline & Body mass index \\
\hline & Preoperative intra-aortic balloon pump \\
\hline & Trainee as operator \\
\hline & Number of grafts \\
\hline & Incomplete revascularization \\
\hline & Cardiopulmonary bypass \\
\hline & Mean age \\
\hline & Male \\
\hline & Female \\
\hline & Body mass index \\
\hline & Ethnicity \\
\hline & Left ventricular function \\
\hline & Prior myocardial infarction \\
\hline & Stroke \\
\hline & Cerebrovascular disease \\
\hline & Aortoiliac peripheral vascular disease \\
\hline & Femoral popliteal peripheral vascular disease \\
\hline & Hemodialysis \\
\hline & Creatinine value $>2.5 \mathrm{mg} / \mathrm{dL}$ \\
\hline & Calcified aorta \\
\hline & Current chronic heart failure \\
\hline & Chronic obstructive pulmonary disease \\
\hline & Diabetes \\
\hline & Hypertension \\
\hline \multirow{5}{*}{ Schwann et $\mathrm{al}^{9}$} & Previous percutaneous coronary intervention \\
\hline & Number of vessel disease \\
\hline & Age \\
\hline & Left ventricular ejection fraction \\
\hline & Completeness of revascularization index \\
\hline
\end{tabular}


TABLE E3. Continued

\begin{tabular}{|c|c|}
\hline Study & Variables \\
\hline Shi et $\mathrm{al}^{10}$ & $\begin{array}{l}\text { Male } \\
\text { Body mass index } \\
\text { Diabetes } \\
\text { Hypercholesterolemia } \\
\text { Chronic obstructive pulmonary disease } \\
\text { Smoker } \\
\text { Previous myocardial infarction } \\
\text { Peripheral vascular disease } \\
\text { Previous surgery } \\
\text { Left main disease } \\
\text { Number of diseased vessels } \\
\text { Number of grafts } \\
\text { Deep sternal infection } \\
\text { Bleeding postoperation } \\
\text { Age } \\
\text { Male } \\
\text { Time of operation } \\
\text { Body mass index } \\
\text { Hypertension } \\
\text { Diabetes } \\
\text { Cerebrovascular disease } \\
\text { Peripheral vascular disease } \\
\text { Previous acute myocardial infarction } \\
\text { Acute myocardial infarction within } 7 \text { d } \\
\text { Previous percutaneous coronary intervention } \\
\text { Non-elective case } \\
\text { Active smoking } \\
\text { Chronic obstructive pulmonary disease } \\
\text { New York Heart Association class } \\
\text { Left ventricular function } \\
\text { Left main disease } \\
\text { Number of vessel disease } \\
\text { Hospital where operation was performed } \\
\text { Number of anastomoses }\end{array}$ \\
\hline
\end{tabular}

STS, Society of Thoracic Surgeons. 
TABLE E4. Newcastle-Ottawa Scale for propensity score-matched studies included in the primary analysis

\begin{tabular}{|c|c|c|c|c|c|c|c|c|}
\hline \multirow[b]{2}{*}{$\begin{array}{l}\text { Study, } \\
\text { total } \\
\text { score }\end{array}$} & \multicolumn{4}{|c|}{ Selection } & \multirow[b]{2}{*}{$\begin{array}{c}\text { Comparability } \\
\text { of cohorts on } \\
\text { the basis of } \\
\text { the design } \\
\text { or analysis }\end{array}$} & \multicolumn{3}{|c|}{ Outcome } \\
\hline & $\begin{array}{c}\text { Representativeness } \\
\text { of the exposed } \\
\text { cohort }\end{array}$ & $\begin{array}{c}\text { Selection of the } \\
\text { non-exposed } \\
\text { cohort }\end{array}$ & $\begin{array}{c}\text { Ascertainment } \\
\text { of exposure }\end{array}$ & $\begin{array}{l}\text { Demonstration } \\
\text { that outcome of } \\
\text { interest was not } \\
\text { present at start } \\
\text { of study }\end{array}$ & & $\begin{array}{l}\text { Assessment } \\
\text { of outcome }\end{array}$ & $\begin{array}{l}\text { Was follow-up } \\
\text { long enough } \\
\text { for outcomes } \\
\text { to occur }\end{array}$ & $\begin{array}{l}\text { Adequacy of } \\
\text { follow-up } \\
\text { of cohorts }\end{array}$ \\
\hline $\begin{array}{l}\text { Navia et al, }{ }^{5} \\
9^{*}\end{array}$ & $\begin{array}{l}* \text { truly } \\
\text { representative [page } \\
\text { 1: “This is a } \\
\text { retrospective analysis } \\
\text { of prospectively } \\
\text { gathered data over an } \\
\text { 8-year period of all } \\
\text { patients undergoing } \\
\text { off-pum coronary } \\
\text { artery bypass } \\
\text { (OPCAB) at the } \\
\text { Institute } \\
\text { Cardiovascular of } \\
\text { Buenos Aires and } \\
\text { who received total } \\
\text { arterial } \\
\text { revascularization } \\
\text { (TAR) with LITA } \\
\text { grafting and a RITA } \\
\text { or RA bypass as a } \\
\text { second arterial } \\
\text { conduit. From } \\
\text { January } 2003 \text { to May } \\
\text { 2011, a total of } 1700 \\
\text { consecutive patients } \\
\text { (of } 1894 \text { ) were } \\
\text { scheduled for urgent } \\
\text { or elective procedure } \\
\text { undergoing TAR } \\
\text { OPCAB and fulfilled } \\
\text { the inclusion criteria } \\
\text { of our observational } \\
\text { study. A total of } 1447 \\
\text { patients ( } 85.11 \% \text { ) } \\
\text { received BITA } \\
\text { grafting, and } 253 \\
\text { patients (14.89\%) } \\
\text { received LITA-RA } \\
\text { grafting."] }\end{array}$ & $\begin{array}{l}\text { = drawn from the } \\
\text { same community as } \\
\text { the exposed cohort } \\
\text { [page 1: “This is a } \\
\text { retrospective analysis } \\
\text { of prospectively } \\
\text { gathered data over an } \\
\text { 8-year period of all } \\
\text { patients undergoing } \\
\text { off-pum coronary } \\
\text { artery bypass } \\
\text { (OPCAB) at the } \\
\text { Institute } \\
\text { Cardiovascular of } \\
\text { Buenos Aires and } \\
\text { who received total } \\
\text { arterial } \\
\text { revascularization } \\
\text { (TAR) with LITA } \\
\text { grafting and a RITA } \\
\text { or RA bypass as a } \\
\text { second arterial } \\
\text { conduit. From } \\
\text { January } 2003 \text { to May } \\
\text { 2011, a total of } 1700 \\
\text { consecutive patients } \\
\text { (of 1894) were } \\
\text { scheduled for urgent } \\
\text { or elective procedure } \\
\text { undergoing TAR } \\
\text { OPCAB and fulfilled } \\
\text { the inclusion criteria } \\
\text { of our observational } \\
\text { study. A total of } 1447 \\
\text { patients ( } 85.11 \% \text { ) } \\
\text { received BITA } \\
\text { grafting, and } 253 \\
\text { patients (14.89\%) } \\
\text { received LITA-RA } \\
\text { grafting."] }\end{array}$ & $\begin{array}{l}*=\text { secure record [page } \\
\text { 2: "Preoperative, } \\
\text { operative, and } \\
\text { postoperative data } \\
\text { were obtained by } \\
\text { retrospective review } \\
\text { of clinical and } \\
\text { pathology reports } \\
\text { from the database and } \\
\text { crosschecked with all } \\
\text { medical charts."] } \\
\end{array}$ & & $\begin{array}{l}* * \text { study controls for * } \\
\text { several variables } \\
\text { (PSM study) [page 2: } \\
\text { "Propensity score } \\
\text { matching was used to } \\
\text { reduce the impact of } \\
\text { treatment selection in } \\
\text { comparing RA and } \\
\text { RITA as the second } \\
\text { conduit for TAR."] }\end{array}$ & $\begin{array}{l}\text { = record linkage } \\
\text { [page 2: } \\
\text { "Preoperative, } \\
\text { operative, and } \\
\text { postoperative data } \\
\text { were obtained by } \\
\text { retrospective review } \\
\text { of clinical and } \\
\text { pathology reports } \\
\text { from the database and } \\
\text { crosschecked with all } \\
\text { medical charts... } \\
\text { Late events were } \\
\text { achieved by direct } \\
\text { communication with } \\
\text { the patient, their } \\
\text { family, and attending } \\
\text { physician, and } \\
\text { medical records were } \\
\text { revised."] }\end{array}$ & $\begin{array}{l}* \text { yes [page } 4: \\
\text { "Median follow-up } \\
\text { of all patients was } \\
1364.5 \mathrm{~d} \text { (IQR, 724- } \\
1984 \mathrm{~d}) \text {. Median } \\
\text { follow-up of the } \\
\text { BITA group was } \\
1283 \mathrm{~d} \text { (IQR, 697- } \\
1861 \mathrm{~d}) . \text { Median } \\
\text { follow-up of the } \\
\text { LITA-RA group was } \\
\text { 2080 d (IQR, 1313- } \\
\text { 2587 d) }(P<.001) . \\
\text { There was no } \\
\text { difference in the } \\
\text { proportion of patients } \\
\text { with completed } \\
\text { follow-up: BITA 94\% } \\
\text { vs LITA-RA 95.3\% } \\
(P=.39) . "\end{array}$ & $\begin{array}{l}* \text { subjects lost to } \\
\text { follow-up unlikely to } \\
\text { introduce bias [page } \\
4: \text { "Median follow- } \\
\text { up of all patients was } \\
1364.5 \mathrm{~d} \text { (IQR, } 724- \\
1984 \mathrm{~d}) \text {. Median } \\
\text { follow-up of the } \\
\text { BITA group was } \\
\text { 1283 d (IQR, 697- } \\
1861 \mathrm{~d}) \text {. Median } \\
\text { follow-up of the } \\
\text { LITA-RA group was } \\
\text { 2080 d (IQR, 1313- } \\
\text { 2587 d) }(P<.001) . \\
\text { There was no } \\
\text { difference in the } \\
\text { proportion of patients } \\
\text { with completed } \\
\text { follow-up: BITA } 94 \% \\
\text { vs LITA-RA } 95.3 \% \\
(P=.39) \text {." }\end{array}$ \\
\hline $\begin{array}{l}\text { Pevni et al } \\
9^{6}\end{array}$ & $\begin{array}{l}* \text { truly } \\
\text { representative. } \\
\text { [page 2: "This } \\
\text { retrospective review } \\
\text { of medical records } \\
\text { and telephone } \\
\text { questionnaires } \\
\text { obtaining follow-up } \\
\text { was approved by the } \\
\text { Institutional Review } \\
\text { Board of the Tel Aviv } \\
\text { Medical Center. } \\
\text { Between } 1996 \text { and } \\
\text { 2010, a total of } 3165 \\
\text { consecutive patients } \\
\text { with multivessel } \\
\text { coronary artery } \\
\text { disease underwent } \\
\text { left-sided arterial } \\
\text { revascularization at } \\
\text { the center. They } \\
\text { constituted } 74.9 \% \text { of }\end{array}$ & 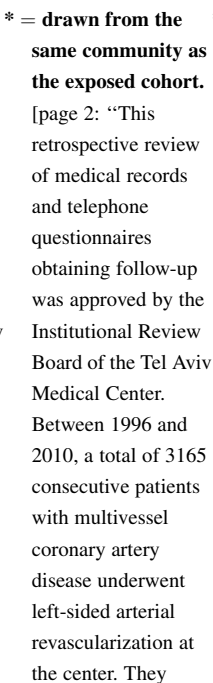 & $\begin{array}{l}\text { * = secure record. } \\
\text { [page 2: "This } \\
\text { retrospective review } \\
\text { of medical records } \\
\text { and telephone } \\
\text { questionnaires } \\
\text { obtaining follow-up } \\
\text { was approved by the } \\
\text { Institutional Review } \\
\text { Board of the Tel Aviv } \\
\text { Medical Center."] } \\
\text { v }\end{array}$ & $*$ yes. & $\begin{array}{l}\text { ** = study controls for * } \\
\text { several variables } \\
\text { (PSM study). [page } \\
\text { 3: "Propensity score } \\
\text { was used to account } \\
\text { for differences } \\
\text { between groups in } \\
\text { preoperative } \\
\text { characteristics."] }\end{array}$ & $\begin{array}{l}\text { = record linkage. } \\
\text { [page 2: "This } \\
\text { retrospective review } \\
\text { of medical records } \\
\text { and telephone } \\
\text { questionnaires } \\
\text { obtaining follow-up } \\
\text { was approved by the } \\
\text { Institutional Review } \\
\text { Board of the Tel Aviv } \\
\text { Medical Center."] }\end{array}$ & $\begin{aligned} *= & \text { yes. [page } 4: \\
& \text { "Follow-up was } 97 \% \\
& \text { complete. The } \\
& \text { median follow-up } \\
& \text { was } 14.19 \text { (95\% CI } \\
& 13.43-14.95) \text { years."] }\end{aligned}$ & 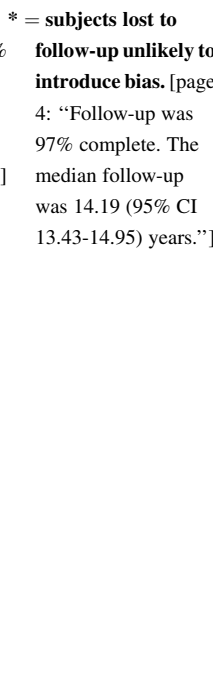 \\
\hline
\end{tabular}


TABLE E4. Continued

\begin{tabular}{|c|c|c|c|c|c|c|c|c|}
\hline \multirow[b]{2}{*}{$\begin{array}{l}\text { Study, } \\
\text { total } \\
\text { score }\end{array}$} & \multicolumn{4}{|c|}{ Selection } & \multirow[b]{2}{*}{$\begin{array}{c}\text { Comparability } \\
\text { of cohorts on } \\
\text { the basis of } \\
\text { the design } \\
\text { or analysis } \\
\end{array}$} & \multicolumn{3}{|c|}{ Outcome } \\
\hline & $\begin{array}{c}\text { Representativeness } \\
\text { of the exposed } \\
\text { cohort }\end{array}$ & $\begin{array}{c}\text { Selection of the } \\
\text { non-exposed } \\
\text { cohort }\end{array}$ & $\begin{array}{l}\text { Ascertainment } \\
\text { of exposure }\end{array}$ & $\begin{array}{c}\text { Demonstration } \\
\text { that outcome of } \\
\text { interest was not } \\
\text { present at start } \\
\text { of study }\end{array}$ & & $\begin{array}{l}\text { Assessment } \\
\text { of outcome }\end{array}$ & $\begin{array}{l}\text { Was follow-up } \\
\text { long enough } \\
\text { for outcomes } \\
\text { to occur }\end{array}$ & $\begin{array}{l}\text { Adequacy of } \\
\text { follow-up } \\
\text { of cohorts }\end{array}$ \\
\hline & $\begin{array}{l}\text { primary coronary } \\
\text { artery bypass grafting } \\
\text { procedures for } \\
\text { multivessel disease } \\
\text { that were performed } \\
\text { in our institution } \\
\text { during this time } \\
\text { period. The } \\
\text { composite T-graft } \\
\text { technique was } \\
\text { employed in } 1718 \text { of } \\
\text { them. In } 1329 \\
\text { patients, one IMA (in } \\
\text { most cases, the right) } \\
\text { was attached end-to- } \\
\text { side to the other IMA. } \\
\text { In the remaining } 389 \\
\text { patients, the RA was } \\
\text { connected end-to- } \\
\text { side to the left IMA. } \\
\text { The BIMA grafting } \\
\text { method was the } \\
\text { dominant } \\
\text { revascularization } \\
\text { procedure performed } \\
\text { in our institution } \\
\text { throughout the study } \\
\text { period for patients } \\
\text { who had multivessel } \\
\text { disease ( } 4247 \\
\text { patients). In all, } 3165 \\
\text { ( } 74.9 \% \text { ) underwent } \\
\text { left-sided arterial } \\
\text { revascularization } \\
\text { ( } 2776 \text { BIMA and } 389 \\
\text { single IMA + RA } \\
\text { procedures); the } \\
\text { remaining } 1082 \\
\text { underwent single } \\
\text { IMA + saphenous } \\
\text { vein grafting.”] }\end{array}$ & $\begin{array}{l}\text { constituted } 74.9 \% \text { of } \\
\text { primary coronary } \\
\text { artery bypass grafting } \\
\text { procedures for } \\
\text { multivessel disease } \\
\text { that were performed } \\
\text { in our institution } \\
\text { during this time } \\
\text { period. The } \\
\text { composite T-graft } \\
\text { technique was } \\
\text { employed in } 1718 \text { of } \\
\text { them. In } 1329 \\
\text { patients, one IMA (in } \\
\text { most cases, the right) } \\
\text { was attached end-to- } \\
\text { side to the other IMA. } \\
\text { In the remaining } 389 \\
\text { patients, the RA was } \\
\text { connected end-to- } \\
\text { side to the left IMA. } \\
\text { The BIMA grafting } \\
\text { method was the } \\
\text { dominant } \\
\text { revascularization } \\
\text { procedure performed } \\
\text { in our institution } \\
\text { throughout the study } \\
\text { period for patients } \\
\text { who had multivessel } \\
\text { disease (4247 } \\
\text { patients). In all, } 3165 \\
\text { (74.9\%) underwent } \\
\text { left-sided arterial } \\
\text { revascularization } \\
\text { (2776 BIMA and } 389 \\
\text { single IMA + RA } \\
\text { procedures); the } \\
\text { remaining 1082 } \\
\text { underwent single } \\
\text { IMA + saphenous } \\
\text { vein grafting.”] }\end{array}$ & & & & & & \\
\hline $\begin{array}{l}\text { Raja et } \mathrm{al}^{7} \\
9^{*}\end{array}$ & $\begin{array}{l}* \text { truly } \\
\text { representative. } \\
\text { [page 2: "We } \\
\text { retrospectively } \\
\text { analysed } \\
\text { prospectively } \\
\text { collected data from } \\
\text { the institutional } \\
\text { surgical database } \\
\text { (PATS; Dendrite } \\
\text { Clinical Systems, } \\
\text { Ltd, Oxford, United } \\
\text { Kingdom) from April } \\
\text { 2001 to May 2013. } \\
\text { The PATS database } \\
\text { captures detailed } \\
\text { information on a wide } \\
\text { range of preoperative, } \\
\text { intraoperative, and } \\
\text { hospital }\end{array}$ & 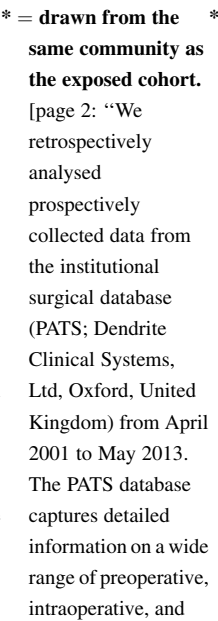 & 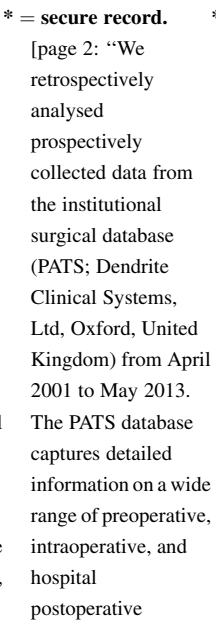 & & $\begin{array}{l}\text { ** = study controls for * } \\
\text { several variables } \\
\text { (PSM study). [page } \\
\text { 3: “To control for } \\
\text { measured potential } \\
\text { confounders in the } \\
\text { data set, a propensity } \\
\text { score (PS) was } \\
\text { generated for each } \\
\text { patient from a } \\
\text { multivariable logistic } \\
\text { regression model } \\
\text { based on } 24 \text { pre- } \\
\text { treatment covariates } \\
\text { as independent } \\
\text { variables with } \\
\text { treatment type (RA vs } \\
\text { RIMA) as a binary } \\
\text { dependent } \\
\text { variables."] }\end{array}$ & $\begin{array}{l}\text { = record linkage. } \\
\text { [page2: "We } \\
\text { retrospectively } \\
\text { analysed } \\
\text { prospectively } \\
\text { collected data from } \\
\text { the institutional } \\
\text { surgical database } \\
\text { (PATS; Dendrite } \\
\text { Clinical Systems, } \\
\text { Ltd, Oxford, United } \\
\text { Kingdom) from April } \\
\text { 2001 to May 2013. } \\
\text { The PATS database } \\
\text { captures detailed } \\
\text { information on a wide } \\
\text { range of preoperative, } \\
\text { intraoperative, and } \\
\text { hospital } \\
\text { postoperative }\end{array}$ & $\begin{array}{l}* \text { yes. [page } 3: \text { "In the } \\
\text { matched sample the } \\
\text { mean follow-up time } \\
\text { was } 8.0 \mathrm{y} \\
\text { [interquartile range: } \\
\text { 3.0e10.3, max 12.2.'] }\end{array}$ & $\begin{array}{l}=\text { subjects lost to } \\
\text { follow-up unlikely to } \\
\text { introduce bias. [page } \\
3: \text { "Fraction missing } \\
\text { ranged from } 0 \% \text { (age) } \\
\text { to } 2.1 \% \text { (HxCHF)."] }\end{array}$ \\
\hline
\end{tabular}


TABLE E4. Continued

\begin{tabular}{|c|c|c|c|c|c|c|c|c|}
\hline \multirow[b]{2}{*}{$\begin{array}{c}\text { Study, } \\
\text { total } \\
\text { score }\end{array}$} & \multicolumn{4}{|c|}{ Selection } & \multirow[b]{2}{*}{$\begin{array}{c}\text { Comparability } \\
\text { of cohorts on } \\
\text { the basis of } \\
\text { the design } \\
\text { or analysis }\end{array}$} & \multicolumn{3}{|c|}{ Outcome } \\
\hline & $\begin{array}{c}\text { Representativeness } \\
\text { of the exposed } \\
\text { cohort }\end{array}$ & $\begin{array}{c}\text { Selection of the } \\
\text { non-exposed } \\
\text { cohort }\end{array}$ & $\begin{array}{c}\text { Ascertainment } \\
\text { of exposure }\end{array}$ & $\begin{array}{c}\text { Demonstration } \\
\text { that outcome of } \\
\text { interest was not } \\
\text { present at start } \\
\text { of study }\end{array}$ & & $\begin{array}{l}\text { Assessment } \\
\text { of outcome }\end{array}$ & $\begin{array}{l}\text { Was follow-up } \\
\text { long enough } \\
\text { for outcomes } \\
\text { to occur }\end{array}$ & $\begin{array}{c}\text { Adequacy of } \\
\text { follow-up } \\
\text { of cohorts }\end{array}$ \\
\hline & $\begin{array}{l}\text { postoperative } \\
\text { variables (including } \\
\text { complications and } \\
\text { mortality) for all } \\
\text { patients undergoing } \\
\text { CABG in our } \\
\text { institution. ...Patients } \\
\text { included in the final } \\
\text { analysis met the } \\
\text { following criteria: a) } \\
\text { first time isolated } \\
\text { CABG; b) } 2 \text { grafts } \\
\text { received; c) surgical } \\
\text { strategies included } \\
\text { single LIMA for the } \\
\text { left anterior } \\
\text { descending (LAD) } \\
\text { artery and the radial } \\
\text { artery for non LAD } \\
\text { targets with or } \\
\text { without additional } \\
\text { saphenous vein grafts } \\
\text { (RA group) or the use } \\
\text { of the bilateral } \\
\text { internal mammary } \\
\text { arteries with or } \\
\text { without additional } \\
\text { saphenous vein grafts } \\
\text { (RIMA group).”] }\end{array}$ & $\begin{array}{l}\text { hospital } \\
\text { postoperative } \\
\text { variables (including } \\
\text { complications and } \\
\text { mortality) for all } \\
\text { patients undergoing } \\
\text { CABG in our } \\
\text { institution....Patients } \\
\text { included in the final } \\
\text { analysis met the } \\
\text { following criteria: a) } \\
\text { first time isolated } \\
\text { CABG; b) } 2 \text { grafts } \\
\text { received; c) surgical } \\
\text { strategies included } \\
\text { single LIMA for the } \\
\text { left anterior } \\
\text { descending (LAD) } \\
\text { artery and the radial } \\
\text { artery for non LAD } \\
\text { targets with or } \\
\text { without additional } \\
\text { saphenous vein grafts } \\
\text { (RA group) or the use } \\
\text { of the bilateral } \\
\text { internal mammary } \\
\text { arteries with or } \\
\text { without additional } \\
\text { saphenous vein grafts } \\
\text { (RIMA group).”] }\end{array}$ & $\begin{array}{l}\text { variables (including } \\
\text { complications and } \\
\text { mortality) for all } \\
\text { patients undergoing } \\
\text { CABG in our } \\
\text { institution. The data } \\
\text { is collected and } \\
\text { reported in } \\
\text { accordance with the } \\
\text { Society for } \\
\text { Cardiothoracic } \\
\text { Surgery in Great } \\
\text { Britain \& Ireland } \\
\text { database criteria. The } \\
\text { database is } \\
\text { maintained by a team } \\
\text { of full-time clinical } \\
\text { information analysts, } \\
\text { who are responsible } \\
\text { for continuous } \\
\text { prospective data } \\
\text { collection as part of a } \\
\text { continuous audit } \\
\text { process. Data } \\
\text { collection is validated } \\
\text { regularly.”] }\end{array}$ & & & $\begin{array}{l}\text { variables (including } \\
\text { complications and } \\
\text { mortality) for all } \\
\text { patients undergoing } \\
\text { CABG in our } \\
\text { institution. The data } \\
\text { is collected and } \\
\text { reported in } \\
\text { accordance with the } \\
\text { Society for } \\
\text { Cardiothoracic } \\
\text { Surgery in Great } \\
\text { Britain \& Ireland } \\
\text { database criteria. The } \\
\text { database is } \\
\text { maintained by a team } \\
\text { of full-time clinical } \\
\text { information analysts, } \\
\text { who are responsible } \\
\text { for continuous } \\
\text { prospective data } \\
\text { collection as part of a } \\
\text { continuous audit } \\
\text { process. Data } \\
\text { collection is validated } \\
\text { regularly." - page } 3 \text { : } \\
\text { "Information about } \\
\text { death from any cause } \\
\text { is regularly obtained } \\
\text { from the General } \\
\text { Register Office } \\
\text { approximately } 1 \text { wk } \\
\text { after the event and } \\
\text { data on repeat } \\
\text { revascularization } \\
\text { from national } \\
\text { surgical and } \\
\text { interventional } \\
\text { database."] }\end{array}$ & & \\
\hline $\begin{array}{l}\text { Ruttmann et al } \\
9^{8}\end{array}$ & $\begin{array}{l}* \text { truly } \\
\text { representative. } \\
\text { [page 2: "This study } \\
\text { analyzes all patients } \\
\text { who underwent } \\
\text { CABG between } \\
\text { August } 2001 \text { and } \\
\text { August } 2010 \text { at the } \\
\text { Innsbruck Medical } \\
\text { University and who } \\
\text { received MAR with a } \\
\text { LITA graft and either } \\
\text { a RITA or RA bypass } \\
\text { as a second arterial } \\
\text { conduit. Inclusion } \\
\text { criteria for this study } \\
\text { were first, non- } \\
\text { emergent isolated } \\
\text { coronary CABG for } \\
\text { multivessel coronary } \\
\text { artery disease } \\
\text { performed by a } \\
\text { median sternotomy }\end{array}$ & $\begin{array}{l}\text { * drawn from the } \\
\text { same community as } \\
\text { the exposed cohort. } \\
\text { [page 2: "This study } \\
\text { analyzes all patients } \\
\text { who underwent } \\
\text { CABG between } \\
\text { August } 2001 \text { and } \\
\text { August } 2010 \text { at the } \\
\text { Innsbruck Medical } \\
\text { University and who } \\
\text { received MAR with a } \\
\text { LITA graft and either } \\
\text { a RITA or RA bypass } \\
\text { as a second arterial } \\
\text { conduit. Inclusion } \\
\text { criteria for this study } \\
\text { were first, non- } \\
\text { emergent isolated } \\
\text { coronary CABG for } \\
\text { multivessel coronary } \\
\text { artery disease } \\
\text { performed by a }\end{array}$ & $\begin{array}{l}\text { * secure record. } \\
\text { [page 2: "Patient data } \\
\text { were prospectively } \\
\text { collected in full } \\
\text { accordance with the } \\
\text { standards of the } \\
\text { Quality Control } \\
\text { Working Group of the } \\
\text { Austrian Society of } \\
\text { Cardiothoracic } \\
\text { Surgery. The data } \\
\text { acquisition included a } \\
\text { telephone interview } \\
\text { by a trained study } \\
\text { nurse a month after } \\
\text { patient discharge to } \\
\text { obtain 30-d mortality } \\
\text { and morbidity. Long- } \\
\text { term follow-up was } \\
\text { performed by } \\
\text { telephone interviews } \\
\text { with patients and } \\
\text { referring }\end{array}$ & $\begin{array}{l}*=\text { yes. } \\
\text { ta } \\
\text { a } \\
\text { a } \\
\text { y- } \\
\text { s }\end{array}$ & $\begin{array}{l}* * \text { study controls for* } \\
\text { several variables } \\
\text { (PSM study). [page } \\
\text { 3: "Propensity score } \\
\text { matching was used to } \\
\text { reduce the impact of } \\
\text { treatment selection in } \\
\text { comparing RA and } \\
\text { RITA as the second } \\
\text { conduit for MAR."] }\end{array}$ & $\begin{array}{l}\text { = record linkage. } \\
\text { [page 2: "Patient data } \\
\text { were prospectively } \\
\text { collected in full } \\
\text { accordance with the } \\
\text { standards of the } \\
\text { Quality Control } \\
\text { Working Group of the } \\
\text { Austrian Society of } \\
\text { Cardiothoracic } \\
\text { Surgery. The data } \\
\text { acquisition included a } \\
\text { telephone interview } \\
\text { by a trained study } \\
\text { nurse a month after } \\
\text { patient discharge to } \\
\text { obtain } 30 \text {-d mortality } \\
\text { and morbidity. Long- } \\
\text { term follow-up was } \\
\text { performed by } \\
\text { telephone interviews } \\
\text { with patients and } \\
\text { referring }\end{array}$ & $\begin{array}{l}\text { * = yes. [page 2: } \\
\text { "Median follow-up } \\
\text { of all patients was } \\
57.7 \text { mo (range 3- } \\
112 \text { mo)."] }\end{array}$ & $\begin{array}{l}\text { no statement (however, } \\
\text { since "late death was } \\
\text { obtained from routine } \\
\text { anniversary follow- } \\
\text { up supplemented } \\
\text { with the Social } \\
\text { Security Death Index } \\
\text { (Statistics Austria } \\
\text { database)," it is } \\
\text { unlikely that a } \\
\text { significant number of } \\
\text { subjects was lost at } \\
\text { follow-up) }\end{array}$ \\
\hline
\end{tabular}


TABLE E4. Continued

\begin{tabular}{|c|c|c|c|c|c|c|c|c|}
\hline \multirow[b]{2}{*}{$\begin{array}{l}\text { Study, } \\
\text { total } \\
\text { score } \\
\end{array}$} & \multicolumn{4}{|c|}{ Selection } & \multirow[b]{2}{*}{$\begin{array}{c}\text { Comparability } \\
\text { of cohorts on } \\
\text { the basis of } \\
\text { the design } \\
\text { or analysis } \\
\end{array}$} & \multicolumn{3}{|c|}{ Outcome } \\
\hline & $\begin{array}{c}\text { Representativeness } \\
\text { of the exposed } \\
\text { cohort }\end{array}$ & $\begin{array}{c}\text { Selection of the } \\
\text { non-exposed } \\
\text { cohort }\end{array}$ & $\begin{array}{c}\text { Ascertainment } \\
\text { of exposure }\end{array}$ & $\begin{array}{c}\text { Demonstration } \\
\text { that outcome of } \\
\text { interest was not } \\
\text { present at start } \\
\text { of study }\end{array}$ & & $\begin{array}{l}\text { Assessment } \\
\text { of outcome }\end{array}$ & $\begin{array}{l}\text { Was follow-up } \\
\text { long enough } \\
\text { for outcomes } \\
\text { to occur } \\
\end{array}$ & $\begin{array}{c}\text { Adequacy of } \\
\text { follow-up } \\
\text { of cohorts }\end{array}$ \\
\hline & $\begin{array}{l}\text { access. Patients } \\
\text { suffering a prior } \\
\text { myocardial infarction } \\
\text { within } 1 \text { wk before } \\
\text { the CABG procedure } \\
\text { were excluded. } \\
\text { Additionally, patients } \\
\text { receiving a bilateral } \\
\text { internal thoracic } \\
\text { artery (BITA) } \\
\text { together with a } \\
\text { concomitant RA (n } \\
89 \text { patients) and } \\
\text { patients receiving a } \\
\text { totally endoscopic } \\
\text { CABG procedure } \\
\text { assisted by the Da } \\
\text { Vinci } \\
\text { telemanipulation } \\
\text { device for multivessel } \\
\text { disease (either } 2- \\
\text { vessel disease or as a } \\
\text { hybrid procedure } \\
\text { with concomitant } \\
\text { percutaneous } \\
\text { coronary intervention } \\
\text { [PCI]) were excluded } \\
\text { from the study (n } 45 \\
\text { patients)."] }\end{array}$ & $\begin{array}{l}\text { median sternotomy } \\
\text { access. Patients } \\
\text { suffering a prior } \\
\text { myocardial infarction } \\
\text { within } 1 \text { wk before } \\
\text { the CABG procedure } \\
\text { were excluded. } \\
\text { Additionally, patients } \\
\text { receiving a bilateral } \\
\text { internal thoracic } \\
\text { artery (BITA) } \\
\text { together with a } \\
\text { concomitant RA (n } \\
89 \text { patients) and } \\
\text { patients receiving a } \\
\text { totally endoscopic } \\
\text { CABG procedure } \\
\text { assisted by the Da } \\
\text { Vinci } \\
\text { telemanipulation } \\
\text { device for multivessel } \\
\text { disease (either 2- } \\
\text { vessel disease or as a } \\
\text { hybrid procedure } \\
\text { with concomitant } \\
\text { percutaneous } \\
\text { coronary intervention } \\
\text { [PCI]) were excluded } \\
\text { from the study (n } 45 \\
\text { patients).”] }\end{array}$ & $\begin{array}{l}\text { cardiologists to } \\
\text { evaluate the freedom } \\
\text { from angina, } \\
\text { myocardial } \\
\text { infarction, death from } \\
\text { all causes, and } \\
\text { cardiac-related } \\
\text { deaths. Additionally, } \\
\text { coronary } \\
\text { angiography reports } \\
\text { in patients who } \\
\text { underwent repeated } \\
\text { cardiac } \\
\text { catheterization were } \\
\text { obtained and } \\
\text { evaluated. Late death } \\
\text { was obtained from } \\
\text { routine anniversary } \\
\text { follow-up } \\
\text { supplemented with } \\
\text { the Social Security } \\
\text { Death Index } \\
\text { (Statistics Austria } \\
\text { database).”] }\end{array}$ & & & $\begin{array}{l}\text { cardiologists to } \\
\text { evaluate the freedom } \\
\text { from angina, } \\
\text { myocardial } \\
\text { infarction, death from } \\
\text { all causes, and } \\
\text { cardiac-related } \\
\text { deaths. Additionally, } \\
\text { coronary } \\
\text { angiography reports } \\
\text { in patients who } \\
\text { underwent repeated } \\
\text { cardiac } \\
\text { catheterization were } \\
\text { obtained and } \\
\text { evaluated. Late death } \\
\text { was obtained from } \\
\text { routine anniversary } \\
\text { follow-up } \\
\text { supplemented with } \\
\text { the Social Security } \\
\text { Death Index } \\
\text { (Statistics Austria } \\
\text { database).”] }\end{array}$ & & \\
\hline $\begin{array}{l}\text { Schwann et al } \\
9^{*}\end{array}$ & $\begin{array}{l}* \text { truly } \\
\text { representative. } \\
\text { [page 2: "Our } \\
\text { analysis included all } \\
\text { multi-vessel coronary } \\
\text { artery disease } \\
\text { patients undergoing a } \\
\text { LITA to left anterior } \\
\text { descending coronary } \\
\text { artery (LAD) CABG } \\
\text { (1987-2011) who } \\
\text { received a total of two } \\
\text { or more coronary } \\
\text { grafts. Patients were } \\
\text { excluded in case of } \\
\text { concomitant aortic, } \\
\text { valvular, congenital } \\
\text { cardiac surgery or } \\
\text { those without an } \\
\text { available US Social } \\
\text { Security Number. } \\
\text { Patients were } \\
\text { retained in case of } \\
\text { concurrent coronary } \\
\text { and/or carotid } \\
\text { endarterectomy. The } \\
\text { final study population } \\
\text { consisted of } 8220 \\
\text { total patients divided } \\
\text { to three grafting } \\
\text { method sub-cohorts; } \\
\text { 4484 received a }\end{array}$ & $\begin{array}{l}\text { * drawn from the } \\
\text { same community as } \\
\text { the exposed cohort. } \\
\text { [page 2: "Our } \\
\text { analysis included all } \\
\text { multi-vessel coronary } \\
\text { artery disease } \\
\text { patients undergoing a } \\
\text { LITA to left anterior } \\
\text { descending coronary } \\
\text { artery (LAD) CABG } \\
\text { (1987-2011) who } \\
\text { received a total of two } \\
\text { or more coronary } \\
\text { grafts. Patients were } \\
\text { excluded in case of } \\
\text { concomitant aortic, } \\
\text { valvular, congenital } \\
\text { cardiac surgery or } \\
\text { those without an } \\
\text { available US Social } \\
\text { Security Number. } \\
\text { Patients were } \\
\text { retained in case of } \\
\text { concurrent coronary } \\
\text { and/or carotid } \\
\text { endarterectomy. The } \\
\text { final study population } \\
\text { consisted of } 8220 \\
\text { total patients divided } \\
\text { to three grafting } \\
\text { method sub-cohorts; }\end{array}$ & $\begin{array}{l}\text { * } \text { secure record. } \\
\text { [page 2: "This } \\
\text { investigation is a } \\
\text { retrospective analysis } \\
\text { of three cardiac } \\
\text { surgery databases } \\
\text { collected } \\
\text { prospectively at the } \\
\text { University of Toledo } \\
\text { Medical Center } \\
\text { (Hospital1, Toledo, } \\
\text { Ohio), Mercy Saint } \\
\text { Vincent Medical } \\
\text { Center (Hospital2, } \\
\text { Toledo, Ohio) and } \\
\text { Yale New Haven } \\
\text { Hospital (YNHH) } \\
\text { (Hospital3, New } \\
\text { Haven, Conn) in } \\
\text { accordance with the } \\
\text { STS National Adult } \\
\text { Cardiac Surgery } \\
\text { Database definitions } \\
\text { and criteria. As the } \\
\text { study period predated } \\
\text { the development of } \\
\text { the STS database, the } \\
\text { earliest data were } \\
\text { abstracted from an } \\
\text { institutional database } \\
\text { and chart review } \\
\text { (YNHH)."] }\end{array}$ & $*$ yes. & $\begin{array}{l}\text { ** = study controls for* } \\
\text { several variables } \\
\text { (PSM study). [page } \\
\text { 3: "To minimize the } \\
\text { confounding effect of } \\
\text { these factors, we used } \\
\text { propensity score } \\
\text { matching to derive } \\
\text { matched triplets with } \\
\text { similar } \\
\text { demographics, risk } \\
\text { factor and operative } \\
\text { parameters."] }\end{array}$ & $\begin{array}{l}\text { = record linkage. } \\
\text { [page 2: "Long-term } \\
\text { mortality data were } \\
\text { secured from } \\
\text { institutional } \\
\text { followups, and from } \\
\text { recurrent (twice } \\
\text { annually, last } \\
\text { November 2011) } \\
\text { searches of the US } \\
\text { Social Security Death } \\
\text { Index (SSDI) } \\
\text { database (http://ssdi. } \\
\text { genealogy.rootsweb. } \\
\text { com)."] }\end{array}$ & $\begin{array}{l}\text { * = yes. [page 2: "The } \\
\text { available study } \\
\text { followup period } \\
\text { ranged between } 3 \text { and } \\
189 \text { mo"] }\end{array}$ & $\begin{array}{l}\text { no statement (however, } \\
\text { since "Long-term } \\
\text { mortality data were } \\
\text { d secured from } \\
\text { institutional } \\
\text { followups, and from } \\
\text { recurrent (twice } \\
\text { annually, last } \\
\text { November 2011) } \\
\text { searches of the US } \\
\text { Social Security Death } \\
\text { Index (SSDI) } \\
\text { database," it is } \\
\text { unlikely that a } \\
\text { significant number of } \\
\text { subjects was lost at } \\
\text { follow-up) }\end{array}$ \\
\hline
\end{tabular}


TABLE E4. Continued

\begin{tabular}{|c|c|c|c|c|c|c|c|c|}
\hline \multirow[b]{2}{*}{$\begin{array}{l}\text { Study, } \\
\text { total } \\
\text { score }\end{array}$} & \multicolumn{4}{|c|}{ Selection } & \multirow[b]{2}{*}{$\begin{array}{c}\text { Comparability } \\
\text { of cohorts on } \\
\text { the basis of } \\
\text { the design } \\
\text { or analysis }\end{array}$} & \multicolumn{3}{|c|}{ Outcome } \\
\hline & $\begin{array}{c}\text { Representativeness } \\
\text { of the exposed } \\
\text { cohort }\end{array}$ & $\begin{array}{c}\text { Selection of the } \\
\text { non-exposed } \\
\text { cohort }\end{array}$ & $\begin{array}{c}\text { Ascertainment } \\
\text { of exposure }\end{array}$ & $\begin{array}{c}\text { Demonstration } \\
\text { that outcome of } \\
\text { interest was not } \\
\text { present at start } \\
\text { of study }\end{array}$ & & $\begin{array}{l}\text { Assessment } \\
\text { of outcome }\end{array}$ & $\begin{array}{l}\text { Was follow-up } \\
\text { long enough } \\
\text { for outcomes } \\
\text { to occur }\end{array}$ & $\begin{array}{l}\text { Adequacy of } \\
\text { follow-up } \\
\text { of cohorts }\end{array}$ \\
\hline & $\begin{array}{l}\text { single arterial (LITA) } \\
\text { graft (SABG group), } \\
3095 \text { received a LITA } \\
\text { with one or more } \\
\text { radial artery grafts } \\
\text { (RA-MABG group) } \\
\text { and } 641 \text { received a } \\
\text { LITA with an } \\
\text { additional RITA graft } \\
\text { (RITA-MABG } \\
\text { group). Patients in the } \\
\text { SABG, RA-MABG } \\
\text { and RITA-MABG } \\
\text { groups may have also } \\
\text { received saphenous } \\
\text { vein grafts (SVG)."'] }\end{array}$ & $\begin{array}{l}4484 \text { received a } \\
\text { single arterial (LITA) } \\
\text { graft (SABG group), } \\
3095 \text { received a LITA } \\
\text { with one or more } \\
\text { radial artery grafts } \\
\text { (RA-MABG group) } \\
\text { and } 641 \text { received a } \\
\text { LITA with an } \\
\text { additional RITA graft } \\
\text { (RITA-MABG } \\
\text { group). Patients in the } \\
\text { SABG, RA-MABG } \\
\text { and RITA-MABG } \\
\text { groups may have also } \\
\text { received saphenous } \\
\text { vein grafts (SVG).'] }\end{array}$ & & & & & & \\
\hline $\begin{array}{l}\text { Shi et al }{ }^{10} \\
9^{*}\end{array}$ & $\begin{array}{l}* \text { truly } \\
\text { representative. } \\
\text { [page 2: "We } \\
\text { reviewed a } \\
\text { multicenter database } \\
\text { containing a total of } \\
\text { 23,343 adult cardiac } \\
\text { procedures } \\
\text { performed from } \\
\text { March 1, 1977, to } \\
\text { December 31, 2010, } \\
\text { across 7 centers } \\
\text { affiliated with the } \\
\text { University of } \\
\text { Melbourne. These } \\
\text { were Austin Hospital, } \\
\text { Epworth Hospital } \\
\text { Richmond, Epworth } \\
\text { Eastern Hospital, } \\
\text { Knox Hospital, Royal } \\
\text { Melbourne Hospital, } \\
\text { St Vincent's Hospital } \\
\text { Melbourne, and } \\
\text { Warringal } \\
\text { Hospital."] }\end{array}$ & 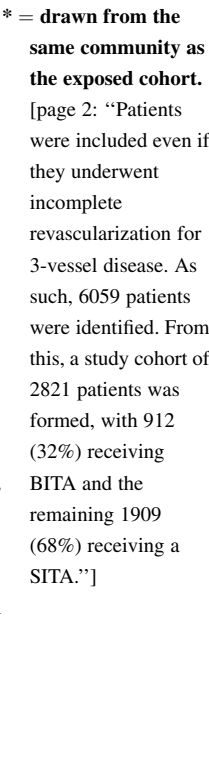 & $\begin{array}{l}\text { * }=\text { secure record. } \\
\text { [page 2: "The } \\
\text { database records } \\
\text { detailed patient } \\
\text { femography, } \\
\text { preoperative risk } \\
\text { factors, operative } \\
\text { technique, } \\
\text { postoperative } \\
\text { hospital course, and } \\
\text { clinical outcomes } \\
\text { including 30-d or in- } \\
\text { hospital morbidity } \\
\text { and mortality. Data } \\
\text { were collected } \\
\text { prospectively. } \\
\text { Survival status of } \\
\text { patients was obtained } \\
\text { from the National } \\
\text { Death Index, which } \\
\text { records all deaths } \\
\text { within Australia."] }\end{array}$ & d & $\begin{array}{l}\text { ** = study controls for } \\
\text { several variables } \\
\text { (PSM study). [page } \\
\text { 3: "Propensity score } \\
\text { matching was } \\
\text { performed to correct } \\
\text { for the bias associated } \\
\text { with the use of } \\
\text { BITAs."] }\end{array}$ & $\begin{array}{l}\text { = record linkage. } \\
\text { [page 2: "Our } \\
\text { primary endpoint was } \\
\text { long-term survival, } \\
\text { and this was obtained } \\
\text { using data from the } \\
\text { Australian National } \\
\text { Death Index."] }\end{array}$ & $\begin{array}{l}* \text { = yes. [page 3: } \\
\text { "Preoperative } \\
\text { s demographic and } \\
\text { investigative data, } \\
\text { d operative variables } \\
\text { and postoperative } \\
\text { (30-d) mortality, } \\
\text { morbidity, and 15-y } \\
\text { survival were } \\
\text { compared between } \\
\text { SITA and BITA study } \\
\text { groups."] }\end{array}$ & $\begin{array}{l}\text { no statement (however, } \\
\text { since "survival status } \\
\text { of patients was } \\
\text { obtained from the } \\
\text { National Death } \\
\text { Index, which records } \\
\text { all deaths within } \\
\text { Australia," it is } \\
\text { unlikely that a } \\
\text { significant number of } \\
\text { subjects was lost at } \\
\text { follow-up) }\end{array}$ \\
\hline $\begin{array}{l}\text { Tranbaugh } \\
9 *\end{array}$ & $\begin{array}{l}* \text { truly } \\
\text { representative. } \\
\text { [page 1: "We } \\
\text { performed a } \\
\text { retrospective cohort } \\
\text { study of our } 2 \\
\text { affiliated institutions' } \\
\text { experiences using } \\
\text { either the RA or the } \\
\text { RITA to bypass the } \\
\text { circumflex coronary } \\
\text { artery during primary } \\
\text { isolated CABG using } \\
\text { the LITA to bypass } \\
\text { the left anterior } \\
\text { descending artery } \\
\text { from January } 1995 \text { to } \\
\text { January } 2009 . \text { Beth } \\
\text { Israel Medical Center } \\
\text { (BIMC) and St. }\end{array}$ & $\begin{array}{l}\text { * drawn from the } \\
\text { same community as } \\
\text { the exposed cohort. } \\
\text { [page 2: "RA use at } \\
\text { BIMC was at first } \\
\text { selective, with } \\
\text { approximately } 33 \% \\
\text { of CABG patients } \\
\text { receiving a RA for } \\
\text { indications of age } \\
\text { younger than } 65 \text { y or } \\
\text { unavailable venous } \\
\text { conduit. } \\
\text { Contraindications to } \\
\text { RA use were } \\
\text { hemodialysis or } \\
\text { chronic renal } \\
\text { insufficiency, } \\
\text { Raynaud's disease, } \\
\text { and, more recently, }\end{array}$ & $\begin{array}{l}\text { * = secure record. } \\
\text { [page 1: "Both } \\
\text { centers maintain an } \\
\text { identical New York } \\
\text { State-mandated, } \\
\text { prospectively } \\
\text { collected database."] }\end{array}$ & $*=$ yes. & $\begin{array}{l}\text { ** = study controls for * } \\
\text { several variables } \\
\text { (PSM study). [page } \\
\text { 2: "A logistic } \\
\text { propensity scoring } \\
\text { model (based on the } \\
\text { following significant } \\
\text { predictors of } \\
\text { treatment probability: } \\
\text { age, sex, ethnicity, } \\
\text { year of surgery, } \\
\text { ejection fraction, } \\
\text { priority, myocardial } \\
\text { infarction, } \\
\text { hypertension, chronic } \\
\text { obstructive } \\
\text { pulmonary disease } \\
\text { [COPD], heart } \\
\text { failure, number of } \\
\text { grafts, number of }\end{array}$ & $\begin{array}{l}\text { = record linkage. } \\
\text { [page 2: "The Social } \\
\text { Security Death Index } \\
\text { (www. } \\
\text { Genealogybank.com) } \\
\text { was searched in } \\
\text { October } 2012 \text { and } \\
\text { was used to identify } \\
\text { patients who died } \\
\text { after hospital } \\
\text { discharge...MAEs } \\
\text { were collected } \\
\text { prospectively and } \\
\text { were defined by the } \\
\text { Department of Health } \\
\text { Cardiac Surgery } \\
\text { Reporting System } \\
\text { (http://www.health. } \\
\text { ny.gov/statistics/ } \\
\text { diseases/ }\end{array}$ & $\begin{array}{l}* \text { = yes. [page } 4 \text { : "Long-n } \\
\text { term follow-up } \\
\text { evaluation averaged } \\
9.0 \pm 4.3 \text { y for the RA } \\
\text { patients and } \\
8.5 \pm 4.6 \text { y for the } \\
\text { RITA patients, with a } \\
\text { range } 0.1 \text { to } 16 \text { y." }\end{array}$ & $\begin{array}{l}\text { no statement (however, } \\
\text { since "the Social } \\
\text { Security Death Index } \\
\text { (www. } \\
\text { Genealogybank.com) } \\
\text { was searched in } \\
\text { October } 2012 \text { and } \\
\text { was used to identify } \\
\text { patients who died } \\
\text { after hospital } \\
\text { discharge," it is } \\
\text { unlikely that a } \\
\text { significant number of } \\
\text { subjects was lost at } \\
\text { follow-up) }\end{array}$ \\
\hline
\end{tabular}


TABLE E4. Continued

\begin{tabular}{|c|c|c|c|c|c|c|c|c|}
\hline \multirow[b]{2}{*}{$\begin{array}{l}\text { Study, } \\
\text { total } \\
\text { score }\end{array}$} & \multicolumn{4}{|c|}{ Selection } & \multirow[b]{2}{*}{$\begin{array}{c}\text { Comparability } \\
\text { of cohorts on } \\
\text { the basis of } \\
\text { the design } \\
\text { or analysis }\end{array}$} & \multicolumn{3}{|c|}{ Outcome } \\
\hline & $\begin{array}{c}\text { Representativeness } \\
\text { of the exposed } \\
\text { cohort }\end{array}$ & $\begin{array}{c}\text { Selection of the } \\
\text { non-exposed } \\
\text { cohort }\end{array}$ & $\begin{array}{c}\text { Ascertainment } \\
\text { of exposure }\end{array}$ & $\begin{array}{c}\text { Demonstration } \\
\text { that outcome of } \\
\text { interest was not } \\
\text { present at start } \\
\text { of study }\end{array}$ & & $\begin{array}{l}\text { Assessment } \\
\text { of outcome }\end{array}$ & $\begin{array}{l}\text { Was follow-up } \\
\text { long enough } \\
\text { for outcomes } \\
\text { to occur } \\
\end{array}$ & $\begin{array}{c}\text { Adequacy of } \\
\text { follow-up } \\
\text { of cohorts }\end{array}$ \\
\hline & $\begin{array}{l}\text { Luke's Roosevelt } \\
\text { Hospital Center } \\
\text { (SLR) are closely } \\
\text { affiliated as part of } \\
\text { Continuum Health } \\
\text { Partners in New York, } \\
\text { NY. Both centers } \\
\text { maintain an identical } \\
\text { New York State- } \\
\text { mandated, } \\
\text { prospectively } \\
\text { collected database. } \\
\text { BIMC used the RA as } \\
\text { the primary second } \\
\text { arterial conduit and } \\
\text { SLR used the free } \\
\text { RITA. Patients } \\
\text { received additional } \\
\text { SV grafts as } \\
\text { needed.”] }\end{array}$ & $\begin{array}{l}\text { radial artery } \\
\text { catheterization. } \\
\text { Overtime, use } \\
\text { gradually increased. } \\
\text { Currently, } 75 \% \text { of all } \\
\text { patients receive a RA } \\
\text { at BIMC using a } \\
\text { liberalized age limit } \\
\text { of younger than } 80 \text { y. } \\
\text { Average total RA use } \\
\text { was } 43 \% \text { over the } \\
\text { past } 17 \text { y whereas } \\
\text { RITA use at SLR has } \\
\text { been consistently } \\
\text { very high at near } \\
\text { 60\%. There are no } \\
\text { age restrictions at } \\
\text { SLR and there were } \\
\text { no contraindications } \\
\text { to using a RITA graft. } \\
\text { These different } \\
\text { institutional grafting } \\
\text { strategies resulted in } \\
\text { a much younger RA } \\
\text { population at BIMC } \\
\text { than the SLR RITA } \\
\text { group, as seen in } \\
\text { Table } 1 . \text { A total of } \\
6566 \text { patients had } \\
\text { isolated primary } \\
\text { CABG using the } \\
\text { LITA at BIMC (n } 1 / 4 \\
4385 \text { ) and at SLR (n } \\
\text { 1/4 } 2181 \text { ) during the } \\
\text { study period. Forty- } \\
\text { one percent of these } \\
\text { patients ( } 2707 \text { ) } \\
\text { received a second } \\
\text { arterial graft, whereas } \\
\text { the other } 3859 \\
\text { patients received a } \\
\text { LITA and SV grafts } \\
\text { (SITA).”] }\end{array}$ & & & $\begin{array}{l}\text { arterial grafts, } \\
\text { hemodialysis, and } \\
\text { triple-vessel disease) } \\
\text { was developed to } \\
\text { summarize covariate } \\
\text { information } \\
\text { regarding treatment } \\
\text { selection (RA vs } \\
\text { RITA) into a single } \\
\text { scalar value } \\
\text { (propensity score } \\
\text { [PS]) and } \\
\text { subsequently was } \\
\text { used in a nearest- } \\
\text { neighbor, caliper- } \\
\text { constrained matching } \\
\text { technique.”] }\end{array}$ & $\begin{array}{l}\text { cardiovascular/index. } \\
\text { htmNYS)."] }\end{array}$ & . & \\
\hline $\begin{array}{l}\text { Tsuneyoshi et a } \\
9^{*}\end{array}$ & $\begin{array}{l}=\text { truly } \\
\text { representative. } \\
\text { [page 2: "A total of } \\
805 \text { patients received } \\
\text { elective isolated } \\
\text { OPCAB at Kurashiki } \\
\text { Central Hospital } \\
\text { between January } \\
2000 \text { and December } \\
\text { 2013. Of these } \\
\text { patients, 232 received } \\
\text { bilateral internal } \\
\text { thoracic arteries } \\
\text { (BITA) and } 152 \\
\text { received single ITA } \\
\text { plus the RA } \\
\text { anastomosed to the } \\
\text { aorta following the } \\
\text { inclusion criteria."] }\end{array}$ & $\begin{array}{l}\text { * drawn from the } \\
\text { same community as } \\
\text { the exposed cohort. } \\
\text { [page 2: "A total of } \\
805 \text { patients received } \\
\text { elective isolated } \\
\text { OPCAB at Kurashiki } \\
\text { Central Hospital } \\
\text { between January } \\
\text { 2000 and December } \\
\text { 2013. Of these } \\
\text { patients, 232 received } \\
\text { bilateral internal } \\
\text { thoracic arteries } \\
\text { (BITA) and } 152 \\
\text { received single ITA } \\
\text { plus the RA } \\
\text { anastomosed to the } \\
\text { aorta following the } \\
\text { inclusion criteria."] }\end{array}$ & $\begin{array}{l}\text { no description } \\
\text { (however, it is likely } \\
\text { that a "secure } \\
\text { record" was used - } \\
\text { see page 2, } \\
\text { "Materials and } \\
\text { methods") }\end{array}$ & 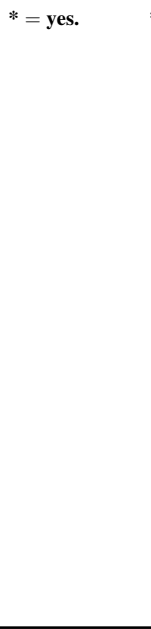 & $\begin{array}{l}* * \text { study controls for * } \\
\text { several variables } \\
\text { (PSM study). [page } \\
\text { 2: “A propensity } \\
\text { score-matched } \\
\text { analysis was } \\
\text { performed using a } \\
\text { multivariate logistic } \\
\text { regression model } \\
\text { based on the } \\
\text { variables, which } \\
\text { revealed a } P \text { value of } \\
\text { less than } 0.2 . ' \text { ] }\end{array}$ & $\begin{array}{l}\text { = record linkage. } \\
\text { [page } 2: \text { :A follow- } \\
\text { up was performed } \\
\text { annually or more } \\
\text { frequently at the } \\
\text { outpatient clinic of } \\
\text { our institution."] }\end{array}$ & $\begin{array}{c}* \text { yes. [page 3: "The } \\
\text { mean follow-up was } \\
6.1 \text { and } 7.8 \text { y for } \\
\text { groups BITA and } \\
\text { LITA + RA, } \\
\text { respectively } \\
(P=.28) . " \text { ] }\end{array}$ & $\begin{array}{l}* \text { subjects lost to } \\
\text { follow-up unlikely to } \\
\text { introduce bias. [page } \\
\text { 2: "The follow-up } \\
\text { rate was } 91 \% . " \text { ] }\end{array}$ \\
\hline
\end{tabular}


TABLE E5. Outcomes definition for sternal wound complications and operative mortality in studies included in the primary analysis

\begin{tabular}{|c|c|c|}
\hline Study & Sternal wound complications & Operative mortality \\
\hline Navia et $\mathrm{al}^{5}$ & $\begin{array}{l}\text { Deep sternal wound infection was defined according to the evidence of } \\
\text { mediastinitis during sternal reexploration }\end{array}$ & Hospital mortality \\
\hline Pevni et $\mathrm{al}^{6}$ & $\begin{array}{l}\text { Deep sternal infection in this setting was defined as the presence of deep } \\
\text { infection, in combination with late dehiscence requiring sternectomy }\end{array}$ & Within $30 \mathrm{~d}$ \\
\hline Raja et $\mathrm{al}^{7}$ & $\begin{array}{l}\text { The incidence of superficial and deep sternal wound infection as defined } \\
\text { by the Centers for Disease Control and Prevention }\end{array}$ & Within $30 \mathrm{~d}$ \\
\hline Ruttmann et $\mathrm{al}^{8}$ & Sternal dehiscence with a need for surgical intervention & Not defined \\
\hline Schwann et $\mathrm{al}^{9}$ & Deep sternal infection not defined & Within $30 \mathrm{~d}$ \\
\hline Shi et al ${ }^{10}$ & Deep sternal wound infection not defined & Within $30 \mathrm{~d}$ \\
\hline Tranbaugh et al ${ }^{11}$ & Deep sternal infection not defined & Within $30 \mathrm{~d}$ \\
\hline Tsuneyoshi et al ${ }^{12}$ & Deep sternal infection was defined as the presence of mediastinitis & Hospital mortality \\
\hline
\end{tabular}

